\title{
Beyond Risk: Bacterial Biofilms and Their Regulating Approaches
}

Musa Hassan Muhammad, Aisha Lawan Idris, Xiao Fan, Yachong Guo, Yiyan Yu, Xu Jin,
Junzhi Qiu, Xiong Guan and Tianpei Huang*

State Key Laboratory of Ecological Pest Control for Fujian and Taiwan Crops \& Key Laboratory of Biopesticide and Chemical Biology of Ministry of Education, College of Life Sciences \& College of Plant Protection \& International College, Fujian

Agriculture and Forestry University, Fuzhou, China

Bacterial biofilms are complex surface attached communities of bacteria held together by self-produced polymer matrixs mainly composed of polysaccharides, secreted proteins, and extracellular DNAs. Bacterial biofilm formation is a complex process and can be described in five main phases: (i) reversible attachment phase, where bacteria non-specifically attach to surfaces; (ii) irreversible attachment phase, which involves interaction between bacterial cells and a surface using bacterial adhesins such as fimbriae and lipopolysaccharide (LPS); (iii) production of extracellular polymeric substances (EPS) by the resident bacterial cells; (iv) biofilm maturation phase, in which bacterial cells synthesize and release signaling molecules to sense the presence of each other, conducing to the formation of microcolony and maturation of biofilms; and (v) dispersal/detachment phase, where the bacterial cells depart biofilms and comeback to independent planktonic lifestyle. Biofilm formation is detrimental in healthcare, drinking water distribution systems, food, and marine industries, etc. As a result, current studies have been focused toward control and prevention of biofilms. In an effort to get rid of harmful biofilms, various techniques and approaches have been employed that interfere with bacterial attachment, bacterial communication systems (quorum sensing, QS), and biofilm matrixs. Biofilms, however, also offer beneficial roles in a variety of fields including applications in plant protection, bioremediation, wastewater treatment, and corrosion inhibition amongst others. Development of beneficial biofilms can be promoted through manipulation of adhesion surfaces, QS and environmental conditions. This review describes the events involved in bacterial biofilm formation, lists the negative and positive aspects associated with bacterial biofilms, elaborates the main strategies currently used to regulate establishment of harmful bacterial biofilms as well as certain strategies employed to encourage formation of beneficial bacterial biofilms, and highlights the future perspectives of bacterial biofilms.

Keywords: bacterial biofilm, biofilm formation, biofilm risk, biofilm promotion, regulation strategy

\section{INTRODUCTION}

It is now understood that about $40-80 \%$ of bacterial cells on earth can form biofilms (Flemming and Wuertz, 2019). The formation of biofilms was detrimental in several situations (Donlan and Costerton, 2002; Dobretsov et al., 2006; Coughlan et al., 2016). For example, in food industries, pathogenic bacteria are able to form biofilms inside of processing facilities, leading to food spoilage, 
and endangering consumer's health (Galie et al., 2018). In hospital settings, biofilms have also been shown to persist on medical device surfaces and on patient's tissues causing persistent infections (Dongari-Bagtzoglou, 2008; Percival et al., 2015). In view of the serious impact of biofilms on human health and other aspects, researchers and the public have long focused on prevention and control of the harmful biofilms.

Despite the negative impacts, bacterial biofilms may also have beneficial effects (Rosche et al., 2009). That is, the formation of bacterial biofilms is often important in agricultural and other industrial settings (Bogino et al., 2013; Berlanga and Guerrero, 2016). These beneficial biofilms are currently used as biological control agents against phytopathogens and biofertilizers to enhance crop production (Timmusk et al., 2017), for bioremediation treatment of hazardous pollutants (Irankhah et al., 2019), for wastewater treatment (Ali et al., 2018), for protection of marine ecosystem (Naidoo and Olaniran, 2013), and for prevention of corrosion (Jayaraman et al., 1997; Martinez et al., 2015). Although biofilms can be beneficial to agriculture and industry, people's understanding of the harmfulside of biofilms has been far better than the benefits for decades. Therefore, the beneficial aspects of biofilms will have great development prospects in the future.

Biofilms are complex surface attached communities of microorganisms held together by self-produced polymer matrixs mainly composed of polysaccharides, secreted proteins, and extracellular DNAs (Tremblay et al., 2013). A biofilm can consist of a single microbial species or a combination of different species of bacteria, protozoa, archaea, algae, filamentous fungi, and yeast that strongly attach to each other and to biotic or abiotic surfaces (Tomaras et al., 2003; Bogino et al., 2013; Silva et al., 2014; Costa-Orlandi et al., 2017; Raghupathi et al., 2017). The ability of microorganisms to develop biofilms has been shown to be an adaptable attribute of microbes (Koczan et al., 2011). The formation of biofilm appears to be an age-old survival mechanism that provides microorganisms with better options compared to their planktonic cells (Dang and Lovell, 2016), including stronger ability to grow in oligotrophic environments (Bowden and Li, 1997), greater access to nutritional resources (Dang and Lovell, 2016), improved survival to biocides (Flemming et al., 2016), enhanced organism productivity and interactions (Roder et al., 2018), as well as greater environmental stability (Dang and Lovell, 2016). It can be seen that biofilms provide protection for bacteria and make them more suitable for the external environment under certain conditions.

Generally, bacterial biofilm formation relies on the interaction between the bacterial cells, the substrates and the surrounding media (Van Houdt and Michiels, 2010). And the formation of bacterial biofilms is a multi-step process starting with reversible attachment to surfaces aided by intermolecular forces and hydrophobicity, and then progress to extracellular polymeric substances (EPS) production which enable the cells to permanently adhere to a surface (Dunne, 2002; Bogino et al., 2013; Caruso et al., 2018). More specially, there are five main phases involved in the biofilm formation process: reversible attachment, irreversible attachment, EPS production, maturation of biofilm, and dispersal/detachment (Stoodley et al., 2002;
Toyofuku et al., 2016). However, the expression and regulation mechanisms of different species of bacteria on various phases of biofilms are quite diverse. Before fully understanding the formation process of all bacterial biofilms, researchers still have a long way to walk.

Nowadays, a variety of approaches, which were mostly concerned with interference against bacterial attachment, signal transduction (quorum sensing interference), and disruption of biofilm architecture, have been applied to inhibit formation of harmful biofilms (Chung and Toh, 2014; Galie et al., 2018). In addition, formation of beneficial biofilms can be encouraged through manipulation of adhesion surfaces, quorum sensing (QS) signals and environmental conditions (Upadhyayula and Gadhamshetty, 2010; Renner and Weibel, 2011; Mangwani et al., 2016). Compared with the researches that promote the formation of beneficial biofilms, the investigation on the prevention and control of harmful biofilms is much deeper.

In order to have a comprehensive understanding of bacterial biofilms beyond risk, this review describes the events involved in bacterial biofilm formation, lists the negative and positive aspects associated with bacterial biofilms, elaborates the main strategies currently used to regulate establishment of harmful bacterial biofilms as well as certain strategies employed to encourage formation of beneficial bacterial biofilms, and highlights the future perspectives of bacterial biofilms.

\section{RISKS OF BACTERIAL BIOFILMS}

Bacteria are able to colonize and form biofilms on virtually all kinds of surfaces, including natural and synthetic surfaces (HallStoodley et al., 2004; Sweet et al., 2011). Biofilms are responsible for chronic illness and nosocomial infections, industrial pipe fouling, spoilage of foods, contamination of sea food, and dairy products as well as ship hull fouling (Zottola and Sasahara, 1994; Schultz et al., 2011; Abdallah et al., 2014; Khatoon et al., 2018). Therefore, the harmful effects of biofilms on human society are manifold.

\section{Healthcare Issues}

In the healthcare settings, biofilms have been shown to develop on medical device surfaces, dead tissues (e.g., sequestra of bones), and inside living tissues (e.g., lung tissue, teeth surfaces; Alav et al., 2018). They may develop on the surface of biomedical devices such as catheters, prosthetic heart valves, pacemakers, breast implants, contact lenses, and cerebrospinal fluid shunts (Table 1; Hall-Stoodley et al., 2004; Wu et al., 2015). Both Gram-positive and Gram-negative bacteria may attach to and develop biofilms on the surfaces of these devices, but the most frequently reported biofilm forming bacteria are Staphylococcus aureus, Staphylococcus epidermidis and Pseudomonas aeruginosa (Hall-Stoodley et al., 2004; Shokouhfard et al., 2015; Khatoon et al., 2018; Pakharukova et al., 2018). It is estimated that about two-thirds of indwelling devices related infections are caused by the staphylococcal species (Khatoon et al., 2018). Bacterial biofilms can also develop in health care water distribution systems. $P$. aeruginosa can form biofilms on inner surfaces of 
TABLE 1 | Biofilm forming bacteria on medical devices.

\begin{tabular}{|c|c|c|}
\hline Medical devices & Biofilm-forming bacteria & References \\
\hline Contact lenses & P. aeruginosa, S. aureus, S. epidermidis, S. saprophyticus, Klebsiella spp. & El-Ganiny et al., 2017 \\
\hline Central venous catheters & Coagulase-negative Staphylococci, S. aureus, Enteric Gram-negative Bacilli & Gominet et al., 2017 \\
\hline Urinary catheters & S. aureus, Enterococcus faecalis, $P$. aeruginosa & Murugan et al., 2016 \\
\hline Peritoneal dialysis catheters & S. epidermidis, P. acnes, S. warneri, S. Iugdunensis, R. mucilaginosa & Pihl et al., 2013 \\
\hline Mechanical heart valves & Streptococcus spp., S. aureus, S. epidermidis, Gram-negative Bacillus, Enterococcus & Jamal et al., 2018 \\
\hline Cerebrospinal fluid shunts & S. aureus, S. epidermidis, Enterococcus faecalis, Enterococcus faecium & Bayston et al., 2012 \\
\hline Breast implants & S. epidermidis, Coagulase-negative Staphylococci, Propionibacterium acnes & Pajkos et al., 2003; Rieger et al., 2013 \\
\hline Orthopaedic implants & S. aureus, S. epidermidis, P. aeruginosa, E. coli, S. haemolyticus & Arciola et al., 2015 \\
\hline Dental implants & Gram-positive cocci, Actinomyces spp., Gram-negative anaerobic oral bacteria & Dhir, 2013; Veerachamy et al., 2014 \\
\hline Voice prostheses & S. aureus, P. aeruginosa, Klebsiella spp., Enterobacterspp., R. dentocariosa, and Proteus spp. & Somogyi-Ganss et al., 2017 \\
\hline Cardiac pacemakers & S. aureus, S. epidermidis & Santos et al., 2011 \\
\hline Intrauterine devices & $\begin{array}{l}\text { E. coli, Streptococcus agalactie, S. aureus, Enterococcus faecalis, Lactobacillus spp., } \\
\text { Prevotella spp., Porphyromonas spp., Bacteroides, Fusobacterium spp. }\end{array}$ & Pal et al., 2005 \\
\hline Biliary stents & $\begin{array}{l}\text { Pseudomonas, Citrobacter, Klebsiella, Staphylococcus, Enterococcus, Aeromonas, Proteus, } \\
\text { Enterobacter }\end{array}$ & Vaishnavi et al., 2018 \\
\hline
\end{tabular}

metal pipes in hospital water system (Loveday et al., 2014). In addition, biofilm forming bacteria contribute to a lot of lifethreatening infections and diseases in humans such as cystic fibrosis (CF), otitis media, periodontitis, infective endocarditis (IE), chronic wounds, and osteomyelitis (Southey-Pillig et al., 2005; Akyildiz et al., 2013; Masters et al., 2019). More specially, $P$. aeruginosa biofilm can cause severe pulmonary infections in patients with CF (Southey-Pillig et al., 2005; Rabin et al., 2015); Haemophilus influenza biofilm is among the causative agents of otitis media (Akyildiz et al., 2013; Bjarnsholt, 2013); Periodontitis, an infection of the gums that damages the soft tissues as well as bones supporting the teeth, is normally caused by the biofilms of Pseudomonas aerobicus and Fusobacterium nucleatum (Jamal et al., 2018); The hypothesis that IE, notoriously difficult to treat, is a biofilm infection explains its resistance to antimicrobials and why surgical disruption and removal of the biofilm improves the chance of cure (Elgharably et al., 2016); $P$. aeruginosa biofilm is also usually formed on chronic wound (Rabin et al., 2015); and Chronic osteomyelitis is a biofilm infection, where microorganisms adhere to dead bone (Zimmerli and Sendi, 2017). It is believed that biofilm-related organisms account for more than $65 \%$ of all microbial infections and exhibit high resistance to antimicrobial agents and components of the host defense system (both innate and adaptive; Jamal et al., 2018; Ciofu and Tolker-Nielsen, 2019). Herein, biofilms have huge impacts on human healthcare.

\section{Plant Diseases}

Biofilm-related diseases have also been reported in agricultural settings. Xanthomonas citri biofilm can cause plant diseases like pierce's disease of grapevines and citrus canker (Ference et al., 2018; Kyrkou et al., 2018). Strong biofilm producer Xylella fastidiosa can also cause pierce's disease of grapevines by blocking the plant vasculature (Rudrappa et al., 2008; Kyrkou et al., 2018). Biofilms have also been implicated in brown spot disease of bean leaves caused by $P$. syringae pv. syringae (Monier and Lindow, 2004; Danhorn and Fuqua, 2007). Similarly, P. aeruginosa biofilm on the roots of Arabidopsis and Ocimum basilicum (sweet basil) can cause mortality in a short time. Ralstonia solanacearum, an important plant pathogenic bacterium reported to form biofilms on the surfaces of xylem vessels, cause bacterial wilt disease in plants (Yao and Allen, 2007; Mori et al., 2016). It is becoming obvious that bacteria can form biofilms when colonizing different plant surfaces.

\section{Food Safety and the Food Industry}

Within the food industry, biofilms can occur on surfaces contacting with, or without foods (Zottola and Sasahara, 1994; Kumar and Anand, 1998). Biofilms are responsible for about $60 \%$ of foodborne outbreaks (Han et al., 2017). Therefore, the presence of biofilms in food processing environments poses significant risk to food safety and the food industry (Galie et al., 2018). In the food processing environments, contaminants mostly come from the surrounding air, equipments, or food surfaces (Kumar and Anand, 1998). Then biofilms growing in food processing environments may lead to spoilage of food, which in turn can cause serious public health risk to consumers and serious economic consequences (Coughlan et al., 2016; Galie et al., 2018). The most common biofilm forming foodborne pathogens and spoilage organisms are Listeria monocytogenes (a ubiquitous species that can cause abortion in pregnant women and other complications in immunocompromised individuals; Galie et al., 2018), Salmonella spp. (a major cause of foodborne diseases which can lead to Reiter's syndrome or even death; Ajene et al., 2013; Wirtanen and Salo, 2016), Escherichia coli 0157:H7 (a strain which is responsible for hemorrhagic colitis; Wirtanen and Salo, 2016), Pseudomonas spp. (a ubiquitous spoilage organism which produces proteases with negative impacts on foods; Rajmohan et al., 2002), Vibrio parahaemolyticus (its infection most commonly associated with consumption of undercooked seafood; Yeung and Boor, 2004), Clostridium perfringens (a species producing different toxins; Wirtanen and Salo, 2016), Campylobacter jejuni (a major cause of human bacterial gastroenteritis; Wirtanen and Salo, 2016), Bacillus spp. 
(a species secreting toxins that can cause diarrhea and emetic syndrome; Galie et al., 2018), S. aureus (a species secreting enteric toxins that cause foodborne intoxications; Argudin et al., 2010), Shewanella putrefaciens (a species producing volatile sulfides, amines, and trimethylamine; Bagge et al., 2001), Cronobacter spp. (a genus mostly causing infections in infants and immunocompromised individuals; Wirtanen and Salo, 2016), and Geobacillus stearothermophilus (a common contaminant of dairy products; Table 2; Burgess et al., 2017). These organisms even can establish multi-species biofilms, which are more stable and difficult to control (Bagge et al., 2001; Coughlan et al., 2016; Han et al., 2016; Wirtanen and Salo, 2016; Galie et al., 2018). Biofilms are also responsible for serious technical challenges of food industry in that they may prevent the flow of heat across equipment surfaces, increase the fluid frictional resistance at the surfaces, and promote the corrosion rate of the surfaces, leading to loss of production efficiency (Chmielewski and Frank, 2003; Meesilp and Mesil, 2019). In a word, biofilms have the danger of direct contamination with pathogenic bacteria in the food industries, as well as the risk of contamination of instruments and equipment.

\section{Drinking Water Distribution Systems}

Biofilms are the predominant mode of microbial growth within the drinking water distribution systems (Mahapatra et al., 2015; Liu et al., 2016). It is well documented that biofilms represent one of the major problems in drinking water distribution systems (Douterelo et al., 2016; Prest et al., 2016). The consumption of contaminated water with pathogenic biofilms has been linked to human infections and waterborne outbreak (Angles et al., 2007; Prest et al., 2016). And the major biofilm producing bacteria in drinking water are $P$. aeruginosa, Campylobacter jejuni, Legionella pneumophila, Mycobacteria, Aeromonas hydrophila, and Klebsiella pneuminiae (Prest et al., 2016; Chan et al., 2019). Since bacterial cells can attach and develop biofilms on the inner surfaces of piping systems from which cells could be detached into the bulk water, they may cause biocorrosion of pipes, undesirable water quality changes affecting color, taste, turbidity and odors, and reduction of heat exchange efficiency (Prest et al., 2016). More specially, the major biofilm producing bacteria known to promote corrosion of metals are sulfate-reducing bacteria, sulfur-oxidizing bacteria, iron-oxidizers, iron-reducers, and manganese-oxidizers (Kip and van Veen, 2015). All in all, biofilms can affect the safety of drinking water and adversely affect water pipelines.

\section{Marine Biofouling}

Marine biofouling portrays the undesirable accumulation of organisms on any natural or man-made objects exposed to seawater (Dobretsov et al., 2013). Common examples of marine substrates include ship hulls and oil or gas installations. Biofouling has been a major challenge in the naval industry and for civilian oceangoing ships (Hopkins and Forrest, 2010; Schultz et al., 2011). Bacteria are among the early microorganisms to settle and colonize substrates in the marine environment and may subsequently facilitate attachment and colonization of larger fouling organisms, such as algae, mussels, and barnacles. Herein, marine biofilms cause biofouling (de Carvalho, 2018). Generally, accumulation of biofoulers by biofilms on ship hulls can increase the hydrodynamic drag of the ships, which causes challenges for shipping industry, including speed reduction, an increase in cleaning time, and greater fuel consumption (Schultz et al., 2011; Demirel et al., 2017). In addition, biofouling of ship hulls has been considered as an important vector for the spread of invasive marine species to new habitats. These transported organisms can adversely affect native species through competition and predation (Minchin and Gollasch, 2003). Therefore, biofilms will affect the cost of ship usage and the balance of marine environment.

\section{BENEFITS OF BACTERIAL BIOFILMS}

Despite their negative impacts in ecosystems, biofilms have positive effects in agricultural, and other industrial settings (Bogino et al., 2013; Berlanga and Guerrero, 2016). That is, they could be used for plant protection, bioremediation, wastewater treatment, prevention of corrosion, and other useful applications (Table 3; Morikawa, 2006; Singh et al., 2006; Edwards and Kjellerup, 2013; Naidoo and Olaniran, 2013; Singh et al., 2019). As researches progress, the beneficial aspects of biofilms will receive more attention.

\section{Plant Protection Agents}

Biofilm formation triggers a number of beneficial effects such as biocontrol and symbiosis. In plants, bacterial biofilms can be formed on the surfaces of leaves, roots, and stems (Morikawa, 2006; Bogino et al., 2013; Schirawski and Perlin, 2018). Biofilmforming rhizobacteria can act as biocontrol agents due to their successful colonization of plants surfaces (Bais et al., 2004; Vejan et al., 2016). Such rhizobacteria belong to Bacillus, Pseudomonas, Streptomyces, Serratia, and Stenotrophomonas (Arrebola et al., 2019). Beneficial bacteria could also be used as biofertilizers to promote plant growth through nitrogen fixation, mineral nutrient uptake, phytohormone production, and disease suppression as well as protection from both biotic and abiotic stresses (Bais et al., 2004; Khan et al., 2018).

The genus Bacillus consists of important plant-associated strains employed for both biocontrol and plant growth promotion (Morikawa, 2006). For example, Bacillus subtilis is a prominent rhizobacterium which is used as an efficient biocontrol and growth promotion agent to protect plants from bacterial and fungal pathogens due to the formation of robust biofilms and the production of several antagonistic metabolites (Bais et al., 2004; Morikawa, 2006). These metabolites mainly include lipopeptides (such as surfactin, iturin, and fengycins), bacteriocins and siderophores (Meena and Kanwar, 2015; Fira et al., 2018). The colonization by B. subtilis in plant roots is associated with surfactin production and biofilm formation, and the surfactin confers protection of plants from pathogen Pseudomonas syringae infection (Bais et al., 2004; Stein, 2005).

A large number of root-associated Pseudomonas spp. can act as biocontrol agents. They can produce a wide range 
TABLE 2 | Representative of foodborne bacteria that can form biofilms.

\begin{tabular}{|c|c|c|c|c|}
\hline Foodborne bacteria & Growing substrate & \multicolumn{2}{|l|}{ Spoiledfood } & References \\
\hline Listeria monocytogenes & $\begin{array}{l}\text { Wastewater pipes, floors, conveyor belts, } \\
\text { rubber seals, elastomers, and stainless steel }\end{array}$ & \multicolumn{2}{|c|}{$\begin{array}{l}\text { Dairy products, melons, coleslaw, ready to eat meat } \\
\text { products and ready to eat fish products }\end{array}$} & Wirtanen and Salo, 2016 \\
\hline Pseudomonas spp. & $\begin{array}{l}\text { Conveyor belts, floors, drains, slicing, and } \\
\text { milking machine }\end{array}$ & \multicolumn{2}{|c|}{ Dairy products, red meat, and poultry } & $\begin{array}{l}\text { Korber et al., 2009; } \\
\text { Møretrø and Langsrud, } 2017\end{array}$ \\
\hline Bacillus cereus & Stainless steel, plastic, soil, and glass wool & \multicolumn{2}{|c|}{$\begin{array}{l}\text { Sprouted seeds, fruit juices, fried rice, pasta dishes, } \\
\text { meat products, vegetables, and milk products }\end{array}$} & $\begin{array}{l}\text { Korber et al., 2009; Wirtanen } \\
\text { and Salo, } 2016\end{array}$ \\
\hline Salmonella & $\begin{array}{l}\text { Stainless steel, elastomers, concrete, glass, } \\
\text { and food surfaces (like lettuce and tomato) }\end{array}$ & \multicolumn{2}{|c|}{ Poultry, pig, cow meats, and dairy products } & Wirtanen and Salo, 2016 \\
\hline Escherichia coli & Stainless steel surfaces, food contact surfaces & \multicolumn{2}{|c|}{$\begin{array}{l}\text { Dairy products, fermented meat sausage, meat, } \\
\text { poultry, fish products, drinks, and vegetables }\end{array}$} & Wirtanen and Salo, 2016 \\
\hline Clostridium & Multi-species biofilm & \multicolumn{2}{|c|}{$\begin{array}{l}\text { Dairy products, fish, cattle meat, poultry, } \\
\text { vegetables, honey, and canned food }\end{array}$} & Wirtanen and Salo, 2016 \\
\hline Cronobacter spp. & $\begin{array}{l}\text { Powder service and powder packaging rooms, } \\
\text { spray-drying areas, and evaporator rooms }\end{array}$ & \multicolumn{2}{|c|}{$\begin{array}{l}\text { Dairy products, vegetables, grains, bread, herbs, } \\
\text { sausages, spices, and meat }\end{array}$} & Wirtanen and Salo, 2016 \\
\hline Staphylococcus & $\begin{array}{l}\text { Stainless steel, plastics (such as polystyrene } \\
\text { and polypropylene), and glass }\end{array}$ & \multicolumn{2}{|c|}{$\begin{array}{l}\text { Dairy products, ready to eat meat products, ready } \\
\text { to eat fish and seafood products, and ready to eat } \\
\text { dairy products }\end{array}$} & Wirtanen and Salo, 2016 \\
\hline Applications & Purposes & & \multicolumn{2}{|c|}{ References } \\
\hline Biofertilizer/biocontrol & \multicolumn{2}{|c|}{ Plant growth promotion and protection against phytopathogens } & \multicolumn{2}{|c|}{ Das et al., 2017} \\
\hline Bioremediation & \multicolumn{2}{|c|}{ Transformation of hazardous pollutants to harmless substances } & \multicolumn{2}{|c|}{ van Dillewijn et al., 2009} \\
\hline Wastewater treatment & \multicolumn{2}{|c|}{ Removal of contaminants from wastewater } & \multicolumn{2}{|c|}{ Yamashita and Yamamoto-Ikemoto, 2014} \\
\hline Microbial fuel cells (MFCs) & \multicolumn{2}{|c|}{ Electricity generation, biohydrogen production, and wastewater treatment } & \multicolumn{2}{|c|}{ Ali et al., 2018} \\
\hline Anticorrosion & \multicolumn{2}{|c|}{ Corrosion inhibition for metals } & \multicolumn{2}{|c|}{ Zuo, 2007} \\
\hline Bioleaching & \multicolumn{2}{|c|}{ Extraction of metals from their ores e.g., copper, nickel, cobalt, zinc } & \multicolumn{2}{|c|}{ Siezen and Wilson, 2009} \\
\hline Biofilm reactor & \multicolumn{2}{|c|}{ Production of fermented products and wastewater treatment } & \multicolumn{2}{|c|}{ Morikawa, 2006} \\
\hline Human gut microbiome & \multicolumn{2}{|c|}{$\begin{array}{l}\text { Production of vitamins, degradation of toxic compounds and conversion of } \\
\text { complex sugar polymers into short-chain fatty acids }\end{array}$} & \multicolumn{2}{|c|}{ de Vos, 2015} \\
\hline
\end{tabular}

of antagonistic compounds, including cyclic lypopeptides, pyrrolnitrin, and phenazines, to prevent proliferation of plant pathogens (Arrebola et al., 2019). For example, priming the seeds with phenazine-producing Pseudomonas chlororaphis can provide protection of barley and oats against seed borne diseases (Chin-A-Woeng et al., 2003); Pseudomonas putida 06909 attaches and colonizes the hyphae of citrus root rotting fungus Phytophthora parasitica by feeding on its exudates and then develop a biofilm around the citrus roots, which prevents further proliferation of the fungus (Steddom et al., 2002; Pandin et al., 2017); and Peanut rhizosphere biofilm formation by Paenibacillus polymyxa provides protection of peanut plants against crown root rot disease caused by Aspergillus niger (Haggag and Timmusk, 2008). Rhizhosphere colonization of beneficial biofilms usually offer excellent plant growth promotion and protection against phytopathogens (Das et al., 2017).

\section{Bioremediation}

Bioremediation is a process that employs living organisms or their derivatives for treatment of hazardous substances from the environment (soil, water, and air) into lesser or harmless compounds (van Dillewijn et al., 2009). It is thought to be a better option than conventional physical and chemical remediation measures with regard to cost and environmental safety (Singh et al., 2006). Moreover, biofilmmediated remediation methods exhibit higher efficiency in transforming toxic wastes because of improved bioavailability of the pollutants to degrading organisms and enhanced adaptability of degrading microorganisms to different toxic compounds (Upadhyayula and Gadhamshetty, 2010). The process usually occurs as part of microbial metabolism and relies on the enzymatic attack by microbes to convert environmental pollutants into innocuous products (Karigar and Rao, 2011). Numerous microorganisms are capable of transforming wide varieties of environmental pollutants into non-toxic forms (van Dillewijn et al., 2009). Microbial bioremediation can be at the site of contamination (in situ) or off the place of contamination (ex situ; Kapley and Purohit, 2009). It can be achieved through the incorporation of limiting nutrients and electrons (biostimulation) or by the addition of microbes at the polluted sites (bioaugmentation) to promote the transformation process (Mangwani et al., 2016).

Compared with their planktonic counterparts, microorganisms living in biofilms display greater tolerance to contaminants, higher chance of survival and adaptation as well as stronger abilities to decompose different pollutants through catabolic pathways (van Dillewijn et al., 2009). Biofilm forming 
bacteria can efficiently be used in the remediation process as cells are encased within a matrix of EPS, which offers protection against several environmental hazards (Mangwani et al., 2016). In addition, biofilms provide an essential habitat which encourages intercellular gene transfer, cellular communication with QS, cohesion and metabolite diffusion as well as bacterial chemotaxis characteristic (Santos et al., 2018).

Biofilm mediated remediation can harbor diverse species of both aerobic and anaerobic bacteria that often use the degradation of pollutants as an energy source (RodriguezMartinez et al., 2006). During aerobic degradation, bacteria can use oxygen as final electron acceptor to breakdown toxic contaminants into innocuous products, mainly carbon dioxide, and water (Edwards and Kjellerup, 2013; Azubuike et al., 2016). In anaerobic conditions, electron acceptors such as nitrate and sulfate can play the role of oxygen to transform contaminants into less toxic or harmless substances and the byproduct may depend on the electron acceptor (Rodriguez-Martinez et al., 2006).

Currently, there is an increasing interest in the use of bacterial biofilms mediated remediation for removal of different kinds of environmental pollutants like oil spills, persistent organic pollutants (such as polycyclic aromatic hydrocarbons, polychlorinated biphenyls, and polychlorinated ethenes), heavy metals, dyes, explosives, pesticides, and pharmaceutical products (Edwards and Kjellerup, 2013). Hence, biofilm-mediated bioremediation is employed in the industry for remediation of contaminated soil and groundwater (Edwards and Kjellerup, 2013). Pseudomonas, Dehalococcides, Arthrobacter, Bacillus, Alcanivorax, Cycloclasticus, Burkholderia, and Rhodococcus can remediate these pollutants (Dasgupta et al., 2013; Yoshikawa et al., 2017). It is likely that more and more bacterial biofilms will be applied to bioremediation.

\section{Wastewater Treatment}

Nowadays, water contamination caused by industrialization, population growth, and urbanization has become a major global threat (Daud et al., 2017). Wastewater is composed of a broad range of organic and inorganic contaminants originating from storm water, agriculture, industry, domestic, and commercial sewage (Naidoo and Olaniran, 2013). The treatment of wastewater is essential to the protection of aquatic ecosystems and public health (Naidoo and Olaniran, 2013). There are several physicochemical processes for wastewater treatment such as coagulation/flocculation, membrane filtration systems, and electrochemical treatment (Kobya et al., 2009; Francis et al., 2016; Favero et al., 2018). Even though these processes provide effectiveness, they experienced difficulty in removing organic matters in that the main components in the conventional water treatment systems are disinfection and filtration (Hlihor et al., 2017). Bacterial communities have been employed to neutralize and degrade organic and inorganic compounds in wastewater through the use of biofilm-based wastewater treatment technology. Removal of excess nutrients from wastewater is also imperative to avoid aquatic eutrophication which leads to anoxia (Yamashita and Yamamoto-Ikemoto, 2014). The basic nutrients present in wastewater are mostly nitrogen and phosphorous (Yamashita and Yamamoto-Ikemoto, 2014). Hence, among the bacterial species used in wastewater treatment are often denitrifying species or those capable of neutralizing phosphorous (Zielinska et al., 2016).

Biologically active carbon (BAC) process, one of the water treatment biotechnologies, uses granular activated carbon (GAC) as a water filtration media to physically remove waterborne disease causing microorganisms, organic matter and in organic substances (Shirey et al., 2012). After the GAC media particles became exhausted, the rough porous surfaces of this GAC are amenable to colonization of bacteria and formation of bacterial biofilms, which degrade phosphorous and nitrogen-containing compounds, organic carbon as well as other entrapped contaminants in the influent water (Simpson, 2008). Currently, biofilm reactors are developed for wastewater treatment such as membrane reactors, moving beds, fluidized beds, and rotating contactors (Huang et al., 2019).

Biofilms can also be used in bioelectrochemical systems (BESs; Upadhyayula and Gadhamshetty, 2010). BESs are bioreactors that utilize microorganisms as catalysts to convert the energy present in organic wastes into electrical energy (Bajracharya et al., 2016). BESs can facilitate wastewater treatment, bioremediation as well as production of power, fuels and chemicals (Ren et al., 2019). BES electrode surface remodeling has been considered an effective technique to improve the performance of BESs (Ren et al., 2019). Microbial fuel cells (MFCs) are a type of BESs that offer another approach for wastewater treatment in an inexpensive way (Ren et al., 2008; Mei et al., 2017). All sorts of wastewater containing compounds degradable by bacteria can be treated by MFCs, including brewery effluent, petroleum contaminants, domestic wastes, food processing waste, swine manure slurry, landfill leachate, and so on (Franks and Nevin, 2010; Gude, 2016a). MFC uses bacteria in the waste as a biocatalyst to convert the chemical energy present in the wastes to electrical energy using oxidation-reduction reactions (Franks et al., 2010; Angelaalincy et al., 2018). MFCs are primarily made of an anode and a cathode separated by a semi-permeable membrane (Franks et al., 2010). The use of MFCs for wastewater treatment needs a design which permits the passage of wastewater through the cell over the anode surface. Bacterial attachment, colonization and biofilm development occur on the anode surface, the bacteria then oxidize the substrate in wastewater to produce electrons and protons. The electrons released during oxidation flow to the cathode via an electrical circuit to generate current (Ali et al., 2018; Singh et al., 2019). At the cathode, electron acceptors (usually oxygen) react with protons, and electrons to generate water vapor-like reduced compounds (Cao et al., 2019). Most of the MFCs configurations can achieve chemical oxygen demand (COD) removal efficiencies at wastewater treatment (Liu et al., 2004; Min et al., 2005; Gude, 2016b). Liu et al. (2004) were the first to initiate the application of MFCs, which reached $80 \%$ of COD removal efficiency from real domestic wastewater with a maximum electrical power generation of $26 \mathrm{~mW} / \mathrm{m}^{2}$ using a single-chamber MFC. Min et al. (2005) had demonstrated that COD and ammoniacal nitrogen $\left(\mathrm{NH}^{+}{ }_{4}-\mathrm{N}\right)$ removal are $86 \%$ and $83 \%$ with a maximum power output of 
$45 \mathrm{~mW} / \mathrm{m}^{2}$ when a swine wastewater is treated with a dualchambered MFC.

\section{Prevention and Control of Corrosion}

Corrosion has now been widely acknowledged as a big problem in drinking water distribution systems, medical, marine, and food processing industry (Prest et al., 2016; Jia et al., 2017; Guo et al., 2018). Both chemical and biological factors can accelerate the rate of corrosion (Kip and van Veen, 2015). Obviously, the activities of microbes on surfaces of metallic materials can either inhibit or promote corrosion (Zuo, 2007). Different strategies, including protective coatings, biocides, cathodic protection and corrosion inhibitors, have been developed to prevent corrosion (Zuo, 2007). However, more recently there has been increased interest in the use of beneficial bacterial biofilms to prevent corrosion because of their effectiveness, cost effective and nature friendly behavior (Zuo, 2007; Guo et al., 2018). The potential strategies may involve: (i) removal of corrosive substances such as oxygen by aerobic bacteria through respiration; (ii) inactivation of corrosive inducing bacteria like sulfate reducing bacteria by inhibitory antimicrobial compounds secreted within biofilms; (iii) production of protective coats such as $\gamma$-polyglutamate by biofilms; and (iv) biofilms formation serving as a diffusion barrier to hinder dissolution of metals (Zuo, 2007; Guo et al., 2018). A gramicidin-S-producing Bacillus brevis biofilm has been reported to curtail the rate of corrosion in mild steel by suppressing the growth of sulfatereducing bacterium Desulfosporosinus orientis and the ironoxidizing bacterium Leptothrix discophora SP-6 (Zuo et al., 2004). Also, the antimicrobial compounds indolicidin, bactenecin and probactenecin produced by genetically engineered $B$. subtilis biofilm can suppress metal corrosion by inhibiting the growth of D. vulgaris and D. gigas (sulfate-reducing bacteria; Zuo, 2007). Although, both aerobic and anaerobic biofilms are able to reduce corrosion rates on the surfaces of different materials, the aerobic biofilms remarkably suppress metal corrosion, which suggests that oxygen consumption can further enhance corrosion protection (Kip and van Veen, 2015). Anticorrosive approach via beneficial biofilms has been successfully reported for stainless steel, carbon steel, copper, and aluminum (Guo et al., 2018). The use of bacterial biofilms for prevention and control of corrosion is a relatively new direction and deserves special attention.

\section{BIOFILM FORMATION PROCESS}

Bacteria form biofilms in response to environmental stresses such as UV radiation, desiccation, limited nutrients, extreme $\mathrm{pH}$, extreme temperature, high salt concentrations, high pressure, and antimicrobial agents. Herein, the events leading to bacterial biofilm formation are complex (O'Toole et al., 2000; HallStoodley et al., 2004; Lopez et al., 2010; Galie et al., 2018). It is generally believed that biofilm formation starts with a reversible attachment of bacteria onto a surface, followed by the irreversible attachment, usually aided by adhesive structures of bacteria and short-range interactions. Their reversible attachment is progressed through the production of EPS. Later, they develop into an organized structure entrapped in an EPS matrix. Finally, bacterial cells can escape from the mature biofilm and disperse into the environment to colonize new niches (Berne et al., 2015; Hoffman et al., 2015; Limoli et al., 2015; Toyofuku et al., 2016). These phases of biofilm formation are illustrated in Figure 1. Five main phases leading to the development of free-living planktonic life form into a sedentary "biofilm" lifestyle are discussed below.

\section{Reversible Attachment}

Bacterial attachment is the initial step of biofilm formation. It begins with the favorable interaction between a few planktonic cells and substrate surfaces. The bacteria must be transported to the surfaces by Brownian motion, sedimentation, or convection (Palmer et al., 2007). Chemotaxis is the directed movement of bacterial cells toward a nutrient source or chemoattractants (e.g., amino acids and sugars) along a concentration gradient in mobile fluids. It occurs in virtually all microorganisms and can facilitate bacterial growth on surfaces by enabling cell-surface interactions (Vladimirov and Sourjik, 2009; Porter et al., 2011). Once the cells reach a surface, the interaction between the cell surfaces and the conditioned surface depends on the net sum of repulsive or attractive forces generated between the two surfaces. If the attractive forces are greater than the repulsive forces, the bacteria will attach to the surface and vice versa (Dunne, 2002; Carniello et al., 2018). This initial attachment is achieved through the effects of non-specific physical forces such as electrostatic forces, hydrophobic interactions and Lifshitzvan der Waals interactions (Dunne, 2002; Carniello et al., 2018). Bacterial attachment has been interpreted within the scope of the classical Derjaguin, Verwey, Landau, and Overbeek (DVLO) DVLO theory, the extended DVLO model, and the thermodynamic approaches (Perni et al., 2014; Zhang et al., 2015; Carniello et al., 2018). These theories describe attachment as the result of a balance between attractive Lifshitz-van der Waals interactions and repulsive forces, based upon electrostatic forces (Morra and Cassinelli, 1997; Rijnaarts et al., 1999), in addition to hydration forces (Jucker et al., 1998; Hermansson, 1999). In general, the reversible bacterial attachment to a surface involves deposition of a bacteria to a substrate in such a way that the bacteria remain in a two dimensional Brownian motion and can be easily detached from the surface by either bacterial mobility or shearing effects of a fluid flowing over the surface (Li and Tang, 2009; Carniello et al., 2018).

Both inert and biological surfaces can be used for initial bacterial attachment. In fact, any substance coming into contact with bacterial suspension is considered to be a substrate for biofilm growth (Donlan, 2002; Tuson and Weibel, 2013). The physicochemical properties of a substratum surface can affect bacterial attachment and how quickly biofilms develop, including surface roughness, hydrophobicity, surface charge, and presence of conditioning films (Donlan, 2002; Srey et al., 2013).

The relationship between bacterial attachment and surface roughness has been reported for years. However, opinion is divided regarding the effect of roughness on bacterial attachment and biofilm formation. Some studies revealed that the irregularities of abiotic surfaces promote bacterial attachment and biofilm development due to lower shear forces and larger 


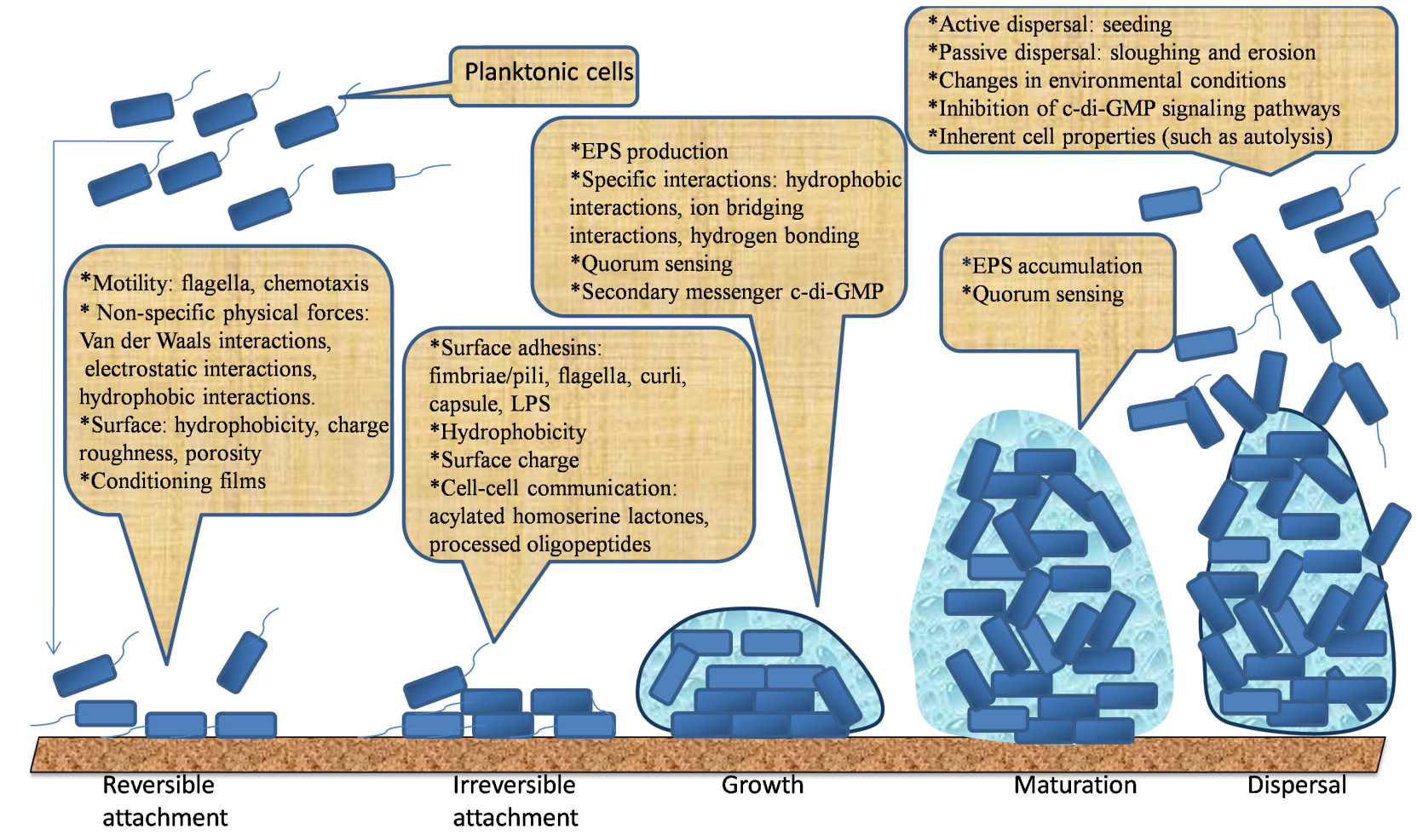

FIGURE 1 | The five main phases leading to the development and dispersal of biofilm.

surface area to which bacterial cells can attach on rougher surfaces (Pedersen, 1990; Bollen et al., 1997; Donlan, 2002; Yu et al., 2016), whereas a contradictory result showed that surface roughness had no influence on bacterial attachment (Vanhaecke et al., 1990; Flint et al., 2000; Zhao et al., 2014). The opposite results may be due to different extracellular structures and physicochemical properties of different bacteria as well as the diverse physicochemical properties of a substratum surface with varied hydrophobicity, surface charge and conditioning films.

Surface hydrophobicity, the strongest long range noncovalent interactions in biological systems, has been thought to play an important role in bacterial attachment. Hydrophobic surfaces seem to be easier for bacteria to colonize than hydrophilic materials (Teixeira and Oliveira, 1999; Donlan and Costerton, 2002; Sousa et al., 2011). This is probably because hydrophobicity reduces repulsive forces between the bacterial surface and colonization substratum. Yu et al. (2016) attributed hydrophobicity and surface roughness of substratum to the early attachment of Streptococcus mutans. Teixeira and Oliveira (1999) also reported the positive correlation between the degree of hydrophobicity of polymeric substrate materials and the number of attached Alcaligenes denetrificans. A notable exception, however, is that $L$. monocytogenes is likely to attach to hydrophilic substrates such as stainless steel than hydrophobic surfaces like polytetrafluoroethylene (PTFE; Chavant et al., 2002). This might be due to the fact that attachment of bacterial cells is also influenced by bacterial surface hydrophobicity, which in turn depends on bacterial growth rate, bacterial species, and growth medium (Vacheethasanee et al., 1998; Katsikogianni and Missirlis, 2004). Vacheethasanee et al. (1998) observed that S. epidermidis strains with higher surface hydrophobicity attached to a greater extent than the ones with less surface hydrophobicity to polyethylene (PE). Studies have shown that hydrophobicity affects attachment of spores to surfaces, and that the more hydrophobic a surface or bacterium, the stronger the attachment (Husmark and Rönner, 1992; Faille et al., 2002). Husmark and Rönner (1992) reported that the hydrophobicity of B. cereus spores and hair like appendages surrounding the spores influenced attachment to inert surfaces. Hydrophobicity of bacteria can be determined by bacterial adherence to hydrocarbons (BATH) also currently known as microbial adherence to hydrocarbons (MATH), hydrophobic interaction chromatography (HIC), and contact angle measurements (Ukuku and Fett, 2002; Palmer et al., 2007). The choice of bacteria to attach to hydrophobic or hydrophilic surfaces depends on the structures and complex physiological and biochemical characteristics of both bacteria and their contacting surfaces.

Surface charge is another physical factor that affects the adhesion of bacteria to substratum. It is widely believed that most bacterial cells have a net negative surface charge due to the presence of considerable amount of carboxyl, amino, and phosphate groups (Dziubakiewicz et al., 2013). Thus, surface that is positively charged promotes bacterial attachment while a negatively charged surface will encourage resistance to bacterial attachment (Tuson and Weibel, 2013). It should be further 
noted that the surface charge of bacteria differs between bacterial species and is influenced by growth medium, bacterial age, $\mathrm{pH}$, and ionic strength (Katsikogianni and Missirlis, 2004). It is often describes by the zeta potential (Palmer et al., 2007). Studies investigating the influence of surface charge on the adhesion ability of $E$. coli to inert surfaces have shown positive relationship in some cases (Dickson and Koohmaraie, 1989; Ukuku and Fett, 2002) and no correlation in the other (Rivas et al., 2007). The discrepancies in these studies could be due to the employed methods, which utilized different growth media and buffers, to demine bacterial surface charge. Similarly, QS in $E$. coli causes an increase in the negative charge on cell surfaces, which in turn promote the association of bacteria with surfaces during the early phases of biofilm formation (Tuson and Weibel, 2013). Electrostatic interaction chromatography (ESIC) has been widely used to measure bacterial surface charge (Ukuku and Fett, 2002).

Nearly all bacteria moving from liquid media toward surfaces make their first contact with conditioning films. The films are essential in the bacterial adhesion process and are formed as a result of adsorption of nutrient molecules onto the material surfaces which lead to changes in physicochemical characteristics of the surfaces and in turn affect the bacterial attachment (Lorite et al., 2011). These films are formed within minutes of exposure with concomitant growth for several hours (Donlan, 2002).

\section{Irreversible Adhesion}

The irreversible attachment is attained through the effects of short range interactions such as dipole-dipole interactions, hydrogen, ionic and covalent bonding, and hydrophobic interactions with involvement of bacterial structural adhesions (Bos et al., 1999). The surface of bacteria is gifted with different adhesins that are projected away from the cell surface into the extracellular environment (Berne et al., 2015). So far, adhesive structures of bacteria, including flagella, pili/fimbriae, and non-fimbrial adhesions, were identified to be involved in the development of biofilms (Berne et al., 2015). The presence of these surface organelles help bacterial cells to make first physical contact with substrates (Petrova et al., 2012; Berne et al., 2015; Carniello et al., 2018). Flagellum is a whip like filamentous appendage concerned with bacterial locomotion (Haiko and Westerlund-Wikstrom, 2013). Flagella driven motility can either be swimming (in liquids) or swarming (on solid moist surfaces). Various species of bacteria exhibit both type of movements to navigate bacterial cells toward a favorable environment and to attach onto a surface (Kearns, 2010; Hintsche et al., 2017). Numerous studies have reported the importance of flagella mediated motility in early attachment and subsequent biofilm formation. Flagella can initiate the adhesion of cells to surfaces by overcoming the repulsive forces that might hinder cell to surface interactions (Van Houdt and Michiels, 2005; Terashima et al., 2008; Lemon et al., 2007; Haiko and Westerlund-Wikstrom, 2013; Wood, 2013). Non-flagellated mutants of L. monocytogenes were impaired in surface adhesion compared to the wild type with short incubation periods. However, with longer times of incubation, surface coverage by non-flagellated mutant cells almost reach the same level as flagellated cells, suggesting that the presence of flagella is crucial for initial and early attachment (Vatanyoopaisarn et al., 2000).

Pili/fimbriae are also filamentous appendages used for bacterial attachment to each other and early cell-surface attachment (Konto-Ghiorghi et al., 2009; Maldarelli et al., 2016). For example, $P$. aeruginosa can employ a pilus mediated form of bacterial surface movement called twitching motility (Alarcon et al., 2009). In K. pneumoniae, Streptococcus agalactiae, Clostridium difficile, and Acinetobacter baumannii, pili play important roles in their early attachment to surfaces (KontoGhiorghi et al., 2009; Maldarelli et al., 2016; Pakharukova et al., 2018). Type 1 and type 3 fimbriae on the surface of K. pneumoniae facilitate attachment on abiotic surfaces and formation of mature biofilm, while only type 1 fimbriae initiate attachment of E. amylovora on abiotic surfaces and biofilm formation (Di Martino et al., 2003; Murphy et al., 2013). And the wild type of E. amylovora attached in greater numbers to surfaces than the mutant type with a deletion in type I fimbriae, which suggests the importance of adhesion structures in the formation of mature biofilms (Koczan et al., 2011). Additionally, thin aggregative fimbriae, also called curli fimbriae and antigen 43 , are found to enhance initial surface attachment of bacteria (Heras et al., 2014; Carter et al., 2016). Moreover, distinct adhesins in some bacteria might be used to mediate transition from transient to permanent surface attachment. For example, formation of the monolayer in Caulobacter crescentus is mediated by a strong adhesive polysaccharide called the holdfast (Karatan and Watnick, 2009). Another example is polysaccharide intercellular adhesin (PIA) produced by S. epidermidis that is essential for cell to cell attachment and subsequent biofilm development (Rohde et al., 2010).

Bacterial pathogens also generate special adhesins that enable them not only adhere to receptors on eukaryotic cell surface but also facilitate their internalization. For instance, Yersinia pseudotuberculosis and Yersinia enterocolitica produce a protein invasin which adheres to $\beta 1$ integrins on the surface of M-cells and causes crossing of Yersinia into M-cells (Bonazzi et al., 2009; Karatan and Watnick, 2009).

A cell-to-cell signaling mechanism called QS also coordinate individual cells to initiate formation of bacterial biofilms (Abraham, 2016). Using QS, bacteria synthesize and release first messengers like chemical signals (autoinducers, AIs) to enable cell-to-cell communication within bacterial population (Li and Tian, 2012; Papenfort and Bassler, 2016). Both Gramnegative and Gram-positive bacteria employ cell-to-cell signaling mechanisms to regulate biofilm formation. Gram-negative bacteria primarily used acyl homoserine lactones (AHLs), whereas Gram-positive bacteria used oligopeptides, universal AIs that can be utilized by both Gram-negative and Grampositive bacteria (Miller and Bassler, 2001; Sperandio et al., 2001; Sun et al., 2004).

\section{EPS Production}

Irreversible adhesion is progressed through the production of EPS regulated by QS of the resident bacterial cells. Bacteria synthesize and secrete EPSs which are an essential component of biofilm extracellular matrix. EPS can mediate both cohesion 
of bacteria and adhesion of biofilms to surfaces via hydrophobic interactions and ion bridging interactions (Fahs et al., 2014; Costa et al., 2018). Overall, EPS plays critical roles in adherence to surfaces, cell-cell recognition, biofilm formation, biofilm structure, retention of water, signaling, protection of cells, symbiosis with plants, trap of nutrients, and genetic exchange (Dogsa et al., 2005; Limoli et al., 2015; Flemming, 2016; Costa et al., 2018). In addition, secondary messenger c-di-GMP is regarded as one of the stimuli for the transition from reversible to irreversible adhesion through the production of EPS and cell surface structures (Toyofuku et al., 2016).

The main constituents of EPS, including polysaccharides, proteins, DNAs, lipids and other polymeric compounds, depend on the bacterial species, and the environmental conditions (Myszka and Czaczyk, 2009; Kostakioti et al., 2013; Limoli et al., 2015; Jayathilake et al., 2017; Bacosa et al., 2018; Costa et al., 2018). Polysaccharides are a major constituent of the EPS matrix and necessary for biofilm development and growth in most bacteria (Flemming et al., 2016). In Gram-negative bacteria, the polysaccharides are usually neutral or polyanionic. The anionic property is considered to be as a result of the presence of uronic acids or ketal-linked pyruvates. This is thought to facilitates association of divalent cations such as magnesium and calcium, which are very important for crosslinking of polymer strands leading to greater binding force in a developed biofilm formation (Donlan, 2002). In Grampositive bacteria such as Staphylococci, however, the EPS is mainly cationic (Donlan, 2002). EPS matrix also contains considerable amounts of proteins such as enzymes and proteinaceous structures like pili and fimbriae. Besides, DNA is an integral part of EPS matrix which acts as an intercellular connector (Flemming et al., 2016). Lipids found in the matrix also play important roles for the attachment of Thiobacillus ferrooxidans (Flemming et al., 2016).

\section{Biofilm Maturation}

At this phase, the genetic machineries of EPS such as a 15 gene-long epsA-O cluster concerning biofilm formation in Bacillus subtilis become activated when intensity of the AIs exceed certain threshold. Bacteria continue to multiply within embedded EPS matrix by using the AIs signals, and conduct to formation of microcolonies and maturation of biofilms (Lopez et al., 2010; Toyofuku et al., 2016). Following microcolony formation and EPS accumulation, changes in gene expressions are induced, and the products of these genes are utilized for the production of EPS that act as biological "glue" between embedded bacterial cells (Frederick et al., 2011; Karimi et al., 2015). The formation of matrix is followed by formation of waterfilled channels which act like circulatory systems, conveying nutrients to the cells communities and removing unwanted products (Garnett and Matthews, 2012). Structural analysis of the microcolonies often shows a pyramid/mushroom-shaped multicellular structure (Garnett and Matthews, 2012). During the process of maturation, motility is restricted within the microcolonies as the production of bacterial surface structures is inhibited, and the gene expression pattern of the sessile cells differs significantly from the planktonic cells. For example, more than 57 biofilm associated proteins, that were not present in the planktonic cells, have been detected in $P$. aeruginosa microcolony (Hall-Stoodley and Stoodley, 2002). Moreover, QS enables communication among bacteria of the same or different species through secretion and detection of AIs. Bacteria use these signaling molecules to sense the presence of each other and to regulate gene expression in response to changes of their population density (Kaplan, 2010; Guttenplan and Kearns, 2013; Wei and Ma, 2013; Berlanga and Guerrero, 2016). Herein, AIs have an important role in maintaining existing biofilms.

\section{Dispersal/Detachment}

The biofilm detachment process, also known as dispersal, represents the terminal process of biofilm development. It is regarded as a strategy of bacterial cells to leave biofilms and continue another biofilm life cycle (Singh et al., 2017). That is, dispersal of surface attached cells from biofilms is a naturally program phenomenon which allows bacterial cells to form new microcolonies on other fresh substrates in response to particular physiological or environmental conditions (DiazSalazar et al., 2017). Dispersal is a complex process regulated by environmental signals, signal transduction pathways, and effectors (Kaplan, 2010).

Although the dispersal mechanisms vary among bacteria, the whole process can still be divided into three common stages: detachment of cells from the microcolonies, movement of cell to a fresh substrate, and adhesion of the cells to the new substrate (Kaplan, 2010; Shen et al., 2018). Furthermore, the detachment can be an active action (i.e., seeding) that cells in biofilms initiate the detachment of themselves in response to changes in their environment such as antimicrobial stress, matrix-degrading enzymes and nutrient starvation, or passive behaviors (i.e., sloughing and erosion) mediated by external forces such as shear forces (Kaplan, 2010; Fleming and Rumbaugh, 2017; Lee and Yoon, 2017). In other words, seeding dispersal is the active detachment mechanism associated with rapid release of microcolonies or planktonic cells from the center of the biofilm, leaving an empty hollow cavity; Sloughing is the sudden detachment of a large portion of a biofilm; Erosion is a release of small portion bacteria from the biofilm. Aggregatibacter actinomycetemcomitans, $P$. aeruginosa, Serratia marcescens, and S. aureus can exhibit seeding dispersal of biofilms (Kaplan, 2010; Lee and Yoon, 2017).

During active dispersal, genes involved in cell motility, such as flagella synthesis and EPS degradation are usually up-regulated, while genes related to EPS production (i.e., polysaccharide synthesis), attachment, and fimbriae synthesis are often down-regulated (Kostakioti et al., 2013). Another effective way to disperse biofilm is to inhibit the c-diGMP signaling pathways because reduction of intracellular c-di-GMP levels will either inhibit biofilm development or enhance biofilm dispersal (Kaplan, 2010). Furthermore, environmental factors like temperature change, $\mathrm{pH}$, nutrients, and oxygen deficiency can contribute to biofilm dispersal (Kostakioti et al., 2013). For example, limited oxygen 
supply facilitates biofilm detachment by promoting c-diGMP degradation. An increase in glucose supply can decrease intracellular c-di-GMP, resulting in the raise of flagella synthesis that eases detachment process (Lee and Yoon, 2017). Moreover, there are various physicochemical parameters and inherent cell properties such as autolysis that facilitate biofilm dispersal (Kaplan, 2010; Kostakioti et al., 2013; Lee and Yoon, 2017).

\section{REGULATING APPROACHES FOR BACTERIAL BIOFILMS}

Unlike the planktonic bacteria, biofilms are not effectively eliminated by ordinary cleaning, washing and disinfection methods (LeChevallier et al., 1988; Somers and Wong, 2004). The formation of biofilm, however, can also play beneficial roles (Morikawa, 2006; Singh et al., 2006; Edwards and Kjellerup, 2013; Naidoo and Olaniran, 2013; Singh et al., 2019). Therefore, multiple factors have also been explored to promote formation of beneficial biofilms (Ansari et al., 2012). Herein, there are different strategies developed to prevent, control or promote bacterial biofilm development, which are closely related to the regulation of bacterial attachment, signal transduction (quorum sensing interference), and bacterial biofilm matrix (Table 4; Chung and Toh, 2014).

\section{Prevention and Control as Well as Promotion of Bacterial Attachment}

Inhibition of cell attachment is an ideal approach to prevent biofilm formation at an initial phase. Therefore, remodeling the surface or coating the surface with the substances that do not encourage the bacterial adhesion could probably impede establishment of bacterial biofilm (Rogers et al., 1994; Chung and Toh, 2014).

Antibiofilm surfaces can mainly be divided into antifouling surfaces and antibacterial ones. The former prevents bacterial attachment onto the surfaces while the latter kills bacteria on the surfaces (Xu et al., 2005; Li et al., 2018). Coating agents and paints such as silver, titanium oxide, grapheme, arsenic, mercury oxide, copper oxide, and zinc oxide nanoparticles have been developed and used effectively as antifoulants (Kuang et al., 2018). Recently, poly(ethylene glycol) (PEG) has been the most widely used antifouling coatings in the marine and biomedical industries (Zhang et al., 2017). Surfaces covered with PEG have been shown to resist the adhesion of bacteria, because of the hydrophilic surface property. PEG coatings are able to repel quite a number of bacterial species like S. aureus, S. epidermidis, P. aeruginosa, and E. coli (Roosjen et al., 2003; Roosjen et al., 2005). Antibacterial surfaces are designed for indwelling medical devices (e.g., catheters and endotracheal tube), which can be colonized by biofilm forming bacteria, to release antibiotics, bacteriocins, metal ions, plant extracts or nanoparticles against pathogens such as $S$. aureus, Candida albicans, P. aeruginosa, and E. faecalis (Dror et al., 2009; Chung and Toh, 2014; Sanchez et al., 2016; Kuang et al.,
2018; Vasilev et al., 2018). Inhibition of biofilm formation can be achieved on medical device surfaces through coating with silver (Bazaka et al., 2012; Francolini et al., 2017). The mechanism of action of silver-based materials is mainly related with the release of silver ion $\left(\mathrm{Ag}^{+}\right)$from the surface, and the required amount for an optimal effect ranging from $10 \mu \mathrm{M}$ to 10 MM (Bazaka et al., 2012; Francolini et al., 2017). Similarly, quaternary ammonium compounds (QACs) are widely used as antibacterial agents for contact killing coatings. Contrary to the antibiotic-release mechanism of silver ions, QACs coatings have a long-lasting contact based antimicrobial mechanism (Hasan et al., 2013; Achinas et al., 2019). Unfortunately, contact killing surfaces have the drawback that some microorganisms are able to develop resistance against these surfaces (Hasan et al., 2013). What's more, small molecules like aryl rhodanines can prevent the early phases of biofilms formed by Grampositive pathogens by inhibiting bacterial adhesion to surfaces (Cegelski et al., 2009; Chung and Toh, 2014). And small synthetic compounds pillicides and curlicides can interfere with bacterial adhesion by inhibiting production of bacterial pili/fimbriae and curli (Cegelski et al., 2009). Natural products honey and tea can also inhibit bacterial attachment (Kuang et al., 2018; Sharahi et al., 2019).

On the other hand, attachment of beneficial bacteria can be promoted by surface modification of materials, which includes both physical and chemical based modification, or electrochemical oxidation treatment (Berlowska et al., 2013; Flexer et al., 2013; Kang et al., 2014).

The surface characteristics can be designed and altered to enhance bacterial attachment and formation of beneficial biofilms for BESs and yeast fermentation industry (Upadhyayula and Gadhamshetty, 2010; Berlowska et al., 2013). The use of nitrogen or oxygen plasma on carbon based materials such as graphite electrodes has been shown to increase surface energy and hydrophilicity which in turn promotes bacterial attachment, biofilm formation and electricity generation in BESs (Flexer et al., 2013). Also, the use of nitrogen plasma on carbon anode can alter surface roughness and hydrophobicity to promote biofilm formation and electricity production in MFCs (He et al., 2012). In addition, carbon felt electrodes treated with UV/O3 can enhance Shewanella oneidensis MR-1 attachment and biofilm formation, leading to increased electron transfer rate and greater current density production in MFCs (Cornejo et al., 2015).

The conversion of ammonium to nitrate (nitrification) is an essential process in wastewater treatment (Lackner et al., 2009). However, the organisms responsible for nitrification have very low growth rates and do not form strong biofilms (Lackner et al., 2009). Hence, efforts need to be made to maintain these nitrifiers in reactor systems (Busscher et al., 1995). It has been proposed that the bond between the attaching bacteria and the materials surface is determinant on biofilm strength and shear resistance (Busscher et al., 1995). Various approaches have been used to promote attachment of nitrifying bacteria onto a membrane surface (Hibiya et al., 2000; Terada et al., 2004; Lackner et al., 2009). Hibiya et al. (2000) observed that the PE membrane whose surface is modified 
TABLE 4 | The regulating approaches for bacterial biofilms.

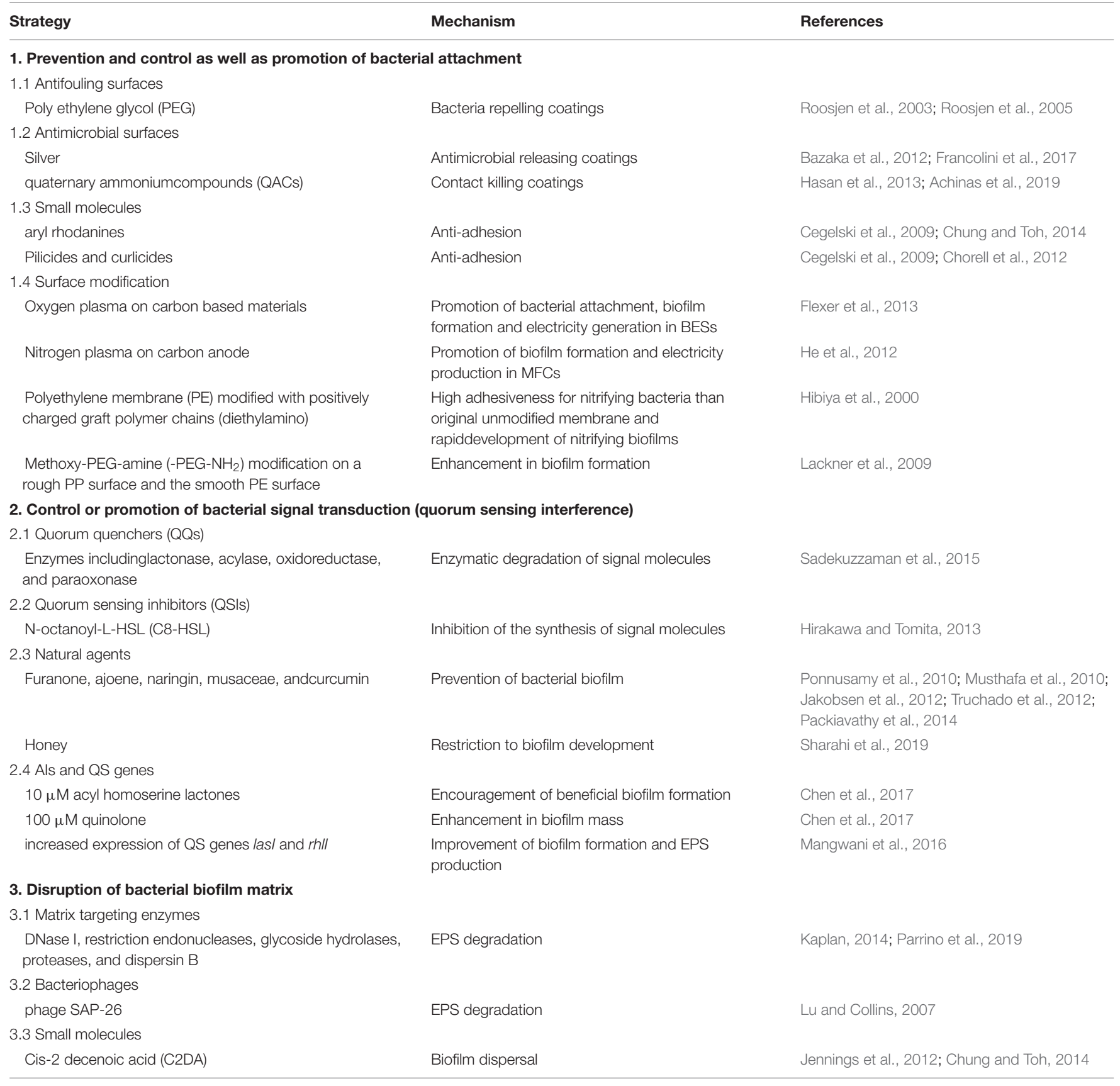

with positively charged graft polymer chains (diethylamino) exhibited a high adhesiveness for nitrifying bacteria than original unmodified membrane, and nitrifying biofilms develop rapidly. Lackner et al. (2009) modified PE and polypropylene (PP) membranes to improve the attachment and shear resistance of nitrifying biofilms. They used a combination of plasma polymerization and wet chemistry to introduce chains of PEG containing two different functional groups (-PEG-NH $\mathrm{N}_{2}$ and -PEG-CH ) to the membrane surfaces. They demonstrated that the methoxy-PEG-amine (-PEG- $\left.\mathrm{NH}_{2}\right)$ modification on a rough $\mathrm{PP}$ surface and the smooth $\mathrm{PE}$ surface had a clear enhancement in biofilm formation. The amino group of methoxy-PEG-amine acts as an attractive force for nitrifiers like Nitrosomonas europea and Nitrobacter winogradskyi, which enhanced formation of biofilm.

\section{Control or Promotion of Bacterial Signal Transduction (Quorum Sensing Interference)}

Bacterial QS depends upon a series of events such as production of signal, signal dissemination, signal receptors, 
signal detection, gene expression, and signaling response. Therefore, quorum quenchers (QQs), or quorum sensing inhibitors (QSIs) that interfere with these processes might potentially inhibit bacterial QS and ultimately biofilm formation (Li and Tian, 2012; Remy et al., 2018). The quorum-quenching approach employing quorum quenching enzymes to inactivate quorum sensing signals is important in healthcare settings and medicine as well as industrial membrane bioreactors, crop production and aquaculture (Fong et al., 2018). Quorum quenching enzymes, lactonase, acylase, oxidoreductase, and paraoxonase, have been discovered in various species of bacteria (Chen et al., 2013). The well-known mechanism of action of QQs is the inactivation of acyl homoserine lactone molecules (Sadekuzzaman et al., 2015). Another mechanism is the inhibition of the synthesis of signal molecules (e.g., AHLs) by QSIs such as N-octanoyl-L-HSL (C8-HSL) that prevents the enzymatic activity of Lux operon proteins (Hirakawa and Tomita, 2013). The natural QSIs known to prevent bacterial biofilm mainly include furanone (Ponnusamy et al., 2010), ajoene (Jakobsen et al., 2012), naringin (Truchado et al., 2012), musaceae (Musthafa et al., 2010), and curcumin (Packiavathy et al., 2014). Moreover, a natural ingredient honey at elevated amount can interfere with genes involved in bacterial communications such as AI2 and LsrA, thereby limiting biofilm development (Sharahi et al., 2019). Furthermore, the presence of a secondary messenger c-di-GMP in elevated amount promotes biofilm formation in bacteria. Therefore, inhibiting the c-di-GMP pathway may be effective method to prevent biofilm formation (Sharahi et al., 2019).

On the other hand, genetic engineering of AIs can encourage beneficial biofilm formation, which plays critical roles in power generation, wastewater treatment and bioremediation (Mangwani et al., 2016; Chen et al., 2017). For example, a decrease in start-up time from 10 days to 4 days in dual chamber MFC was achieved by adding a kind of AIs $(10 \mu \mathrm{M}$ AHLs; Chen et al., 2017). An AI (100 $\mu \mathrm{M}$ quinolone) enhances biofilm mass of extremophile Halanaerobium praevalence on the anode of MFC, leading to effective treatment of high salinity wastewater and improved power generation (Chen et al., 2017). Furthermore, QS bacteria can degrade a broad range of pollutants (Mangwani et al., 2015). The marine $P$. aeruginosa N6P6 biofilm formation and EPS production can be improved by increasing the expression of QS genes lasI and rhlI, which contributes to increase rate of polycyclic aromatic hydrocarbon degradation (Mangwani et al., 2016).

\section{Disruption of Bacterial Biofilm Matrix}

To disperse bacterial biofilms, it's essential to destroy the structural components of EPS (Flemming and Wingender, 2010; Wei and Ma, 2013). Thus, degradation of the EPS matrix can be effective method to interfere with bacterial biofilm formation.

EPS matrix-degrading enzymes, including deoxyribonuclease I (DNase I), restriction endonucleases, glycoside hydrolases, proteases, and dispersin B, can inhibit bacterial biofilm formation and facilitate dispersion of established biofilm colonies (Kaplan, 2014). As soon as the biofilm matrix is enzymatically degraded, the bacterial cells are then released as planktonic cells which are easily eliminated by various antibacterial agents, disinfectants, phages, or immune systems (Kaplan, 2014; Parrino et al., 2019).

Phages can cross the EPS matrix by either diffusion or with the assist of phage-derived enzymes (Sao-Jose, 2018; Simmons et al., 2018). A genetically engineered lytic phage having a biofilm degrading enzyme showed more efficient eradication of biofilm than non-enzymatic phage (Lu and Collins, 2007). Combined with antibiotic rifampicin, the phage SAP-26 was able to cross the biofilm matrix leading to disruption of biofilm architectures (Hughes et al., 1998; Rahman et al., 2011). Cis-2 decenoic acid (C2DA) is a medium-chain fatty acid chemical messenger produced by Paeruginosa to initiate the dispersion of established bacterial biofilms C2DA not only effectively induced biofilm dispersal but may also inhibits initiation of biofilm formation (Jennings et al., 2012; Chung and Toh, 2014).

Therefore, EPS matrix can be destructed with enzymes and phages. As the research progresses, more EPS degradation methods will be found.

\section{CONCLUSION}

Bacterial biofilm formation occurs in sequential and wellregulated events and is the predominant bacterial lifestyle in most natural and man-made environments. The ability of bacteria to colonize surfaces and to establish biofilms are considered serious issues and has been associated with detrimental consequences in many branches related to food, water, pharmacy and healthcare. In an effort to get rid of harmful biofilms, various techniques and approaches have been developed which were mostly concerned with interference against bacterial attachment and QS as well as biofilm matrix destruction. However, bacterial biofilms affect the environments beyond risk. There are numerous beneficial applications of bacterial biofilms. Biofilm-associated bacteria play essential roles in the transformation of hazardous pollutants to harmless substances, the protection of plants against phytopathogens, the plant growth promotion, as well as the removal of excess nutrients from wastewater. Moreover, beneficial biofilms formation can be encouraged in many industrial and environmental areas through surface modification and QS signals.

\section{FUTURE PERSPECTIVES}

Researches on the harmful effects of biofilms on healthcare, agriculture, food industry, drinking water, and oceans will continue to dominate the research field in the near future. However, with the deepening of people's understanding of the dual-sidedness of the role of biofilms more than risks, 
the researches focusing on plant protection, bioremediation, wastewater treatment, and corrosion control of biofilms will be increasing. In addition, with the application of nextgeneration technologies such as various omics to biofilm researches, new bacterial biofilm regulation mechanisms are expected to be discovered. Therefore, researches of biofilms may be carried out in the following aspects in the future:

(1) Control of bacterial biofilms that are harmful to human society;

(2) Utilization of beneficial bacteria with high-production biofilms;

(3) In-depth investigation of regulatory mechanisms for the formation and dispersion of bacterial biofilms, especially researches related to beneficial biofilms;

(4) Elucidation of interaction mechanisms of bacterial biofilms with inanimate or living body interfaces;

(5) Development of new commercial products based on bacterial biofilms;

(6) Exploration of application schemes for bacterial biofilm products.

It is believed that through the unremitting efforts of researchers, biofilms will play more and more important roles in both basic researches and practical applications in recent years.

\section{REFERENCES}

Abdallah, M., Benoliel, C., Drider, D., Dhulster, P., and Chihib, N. E. (2014). Biofilm formation and persistence on abiotic surfaces in the context of food and medical environments. Arch. Microbiol. 196, 453-472. doi: 10.1007/s00203-014-0983-1

Abraham, W. R. (2016). Going beyond the control of quorum-sensing to combat biofilm infections. Antibiotics 5:3. doi: 10.3390/antibiotics5010003

Achinas, S., Charalampogiannis, N., and Euverink, G. J. W. (2019). A brief recap of microbial adhesion and biofilms. Appl. Sci. 9:2801.

Ajene, A. N., Fischer Walker, C. L., and Black, R. E. (2013). Enteric pathogens and reactive arthritis: a systematic review of Campylobacter, salmonella and Shigella-associated reactive arthritis. J. Health Popul. Nutr. 31, 299-307.

Akyildiz, I., Take, G., Uygur, K., Kizil, Y., and Aydil, U. (2013). Bacterial biofilm formation in the middle-ear mucosa of chronic otitis media patients. Indian J. Otolaryngol. Head Neck Surg. 65, 557-561. doi: 10.1007/s12070-0120513-x

Alarcon, I., Evans, D. J., and Fleiszig, S. M. (2009). The role of twitching motility in Pseudomonas aeruginosa exit from and translocation of corneal epithelial cells. Invest. Ophthalmol. Vis. Sci. 50, 2237-2244. doi: 10.1167/iovs.08-2785

Alav, I., Sutton, J. M., and Rahman, K. M. (2018). Role of bacterial efflux pumps in biofilm formation. J. Antimicrob. Chemother. 73, 2003-2020. doi: 10.1093/jac/ dky042

Ali, J., Sohail, A., Wang, L., Rizwan Haider, M., Mulk, S., and Pan, G. (2018). Electro-microbiology as a promising approach towards renewable energy and environmental sustainability. Energies 11:1822.

Angelaalincy, M. J., Navanietha, K. R., Shakambari, G., Ashokkumar, B., Kathiresan, S., and Varalakshmi, P. (2018). Biofilm engineering approaches for improving the performance of microbial fuel cells and bioelectrochemical systems. Front. Energy Res. 6:63. doi: 10.1016/j.biotechadv.2019.107468

Angles, M. L., Chandy, J. P., Cox, P. T., Fisher, I. H., and Warnecke, M. R. (2007). Implications of biofilm-associated waterborne Cryptosporidium oocysts for the water industry. Trends Parasitol. 23, 352-356.

Ansari, M. I., Schiwon, K., Malik, A., and Grohmann, E. (2012). "Biofilm formation by environmental bacteria," in Environmental Protection Strategies

\section{AUTHOR CONTRIBUTIONS}

The idea of this manuscript was conceived by TH. MM wrote the manuscript. AI, XF, YG, YY, and XJ helped to analyze the literatures. TH, XG, and JQ reviewed the manuscript.

\section{FUNDING}

This project was supported by the National Key R\&D Program of China (Nos. 2017YFD0200400, 2017YFE0121700, and 2017YFE0122000), the National Natural Science Foundation of China (No. 31672084), and the State Key Laboratory of Ecological Pest Control for Fujian and Taiwan Crops (No. SKL2018010).

\section{ACKNOWLEDGMENTS}

We thank the teachers and the students of the Biopesticide Research Center for their help. Thanks were also extended to the referees for their conductive comments. The content is solely the responsibility of the authors and does not necessarily represent the official views of the Ministry of Science and Technology, China, the National Natural Science Foundation of China, and the State Key Laboratory of Ecological Pest Control for Fujian and Taiwan Crops, China.

for Sustainable Development, eds A. Malik and E. Grohmann (Dordrecht: Springer Netherlands).

Arciola, C. R., Campoccia, D., Ehrlich, G. D., and Montanaro, L. (2015). Biofilmbased implant infections in orthopaedics. Adv. Exp. Med. Biol. 830, 29-46. doi: 10.1007/978-3-319-11038-7_2

Argudin, M. A., Mendoza, M. C., and Rodicio, M. R. (2010). Food poisoning and Staphylococcus aureus enterotoxins. Toxins 2, 1751-1773. doi: 10.3390/ toxins 2071751

Arrebola, E., Tienda, S., Vida, C., De Vicente, A., and Cazorla, F. M. (2019). Fitness features involved in the biocontrol interaction of Pseudomonas chlororaphis with host plants: the case study of PcPCL1606. Front. Microbiol. 10:719. doi: 10.3389/fmicb.2019.00719

Azubuike, C. C., Chikere, C. B., and Okpokwasili, G. C. (2016). Bioremediation techniques-classification based on site of application: principles, advantages, limitations and prospects. World J. Microbiol. Biotechnol. 32:180. doi: 10.1007/ s11274-016-2137-x

Bacosa, H. P., Kamalanathan, M., Chiu, M. H., Tsai, S. M., Sun, L., and Labonte, J. M. (2018). Extracellular polymeric substances (EPS) producing and oil degrading bacteria isolated from the northern Gulf of Mexico. PLoS One 13:e0208406. doi: 10.1371/journal.pone.0208406

Bagge, D., Hjelm, M., Johansen, C., Huber, I., and Gram, L. (2001). Shewanella putrefaciens adhesion and biofilm formation on food processing surfaces. Appl. Environ. Microbiol. 67, 2319-2325.

Bais, H. P., Fall, R., and Vivanco, J. M. (2004). Biocontrol of Bacillus subtilis against infection of Arabidopsis roots by Pseudomonas syringae is facilitated by biofilm formation and surfactin production. Plant Physiol. 134, 307-319.

Bajracharya, S., Sharma, M., Mohanakrishna, G., Dominguez Benneton, X., Strik, D. P. B. T. B., Sarma, P. M., et al. (2016). An overview on emerging bioelectrochemical systems (BESs): technology for sustainable electricity, waste remediation, resource recovery, chemical production and beyond. Renew. Energy 98, 153-170.

Bayston, R., Ullas, G., and Ashraf, W. (2012). Action of linezolid or vancomycin on biofilms in ventriculoperitoneal shunts in vitro. Antimicrob. Agents Chemother. 56, 2842-2845. doi: 10.1128/AAC.06326-11 
Bazaka, K., Jacob, M. V., Crawford, R. J., and Ivanova, E. P. (2012). Efficient surface modification of biomaterial to prevent biofilm formation and the attachment of microorganisms. Appl. Microbiol. Biotechnol. 95, 299-311. doi: 10.1007/s00253012-4144-7

Berlanga, M., and Guerrero, R. (2016). Living together in biofilms: the microbial cell factory and its biotechnological implications. Microb. Cell Fact. 15:165. doi: $10.2210 / \mathrm{pdb} 4 \mathrm{bhu} / \mathrm{pdb})$

Berlowska, J., Kregiel, D., and Ambroziak, W. (2013). Enhancing adhesion of yeast brewery strains to chamotte carriers through aminosilane surface modification. World J. Microbiol. Biotechnol. 29, 1307-1316. doi: 10.1007/s11274-013-1294-4

Berne, C., Ducret, A., Hardy, G. G., and Brun, Y. V. (2015). Adhesins involved in attachment to abiotic surfaces by gram-negative bacteria. Microbiol. Spectr. 3 . doi: 10.1128/microbiolsec.MB--0018--2015.

Bjarnsholt, T. (2013). The role of bacterial biofilms in chronic infections. APMIS Suppl. 121, 1-51.

Bogino, P. C., Oliva Mde, L., Sorroche, F. G., and Giordano, W. (2013). The role of bacterial biofilms and surface components in plant-bacterial associations. Int. J. Mol. Sci. 14, 15838-15859. doi: 10.3390/ijms140815838

Bollen, C. M., Lambrechts, P., and Quirynen, M. (1997). Comparison of surface roughness of oral hard materials to the threshold surface roughness for bacterial plaque retention: a review of the literature. Dent. Mater. 13, 258-269.

Bonazzi, M., Lecuit, M., and Cossart, P. (2009). Listeria monocytogenes internalin and E-cadherin: from bench to bedside. Cold Spring Harb. Perspect. Biol. 1:a003087. doi: 10.1101/cshperspect.a003087

Bos, R., Van Der Mei, H. C., and Busscher, H. J. (1999). Physico-chemistry of initial microbial adhesive interactions-its mechanisms and methods for study. FEMS Microbiol. Rev. 23, 179-230.

Bowden, G. H., and Li, Y. H. (1997). Nutritional influences on biofilm development. Adv. Dent. Res. 11, 81-99.

Burgess, S. A., Flint, S. H., Lindsay, D., Cox, M. P., and Biggs, P. J. (2017). Insights into the Geobacillus stearothermophilus species based on phylogenomic principles. BMC Microbiol. 17:140. doi: 10.1186/s12866-017-1047-x

Busscher, H. J., Bos, R., and Van Der Mei, H. C. (1995). Initial microbial adhesion is a determinant for the strength of biofilm adhesion. Fems Microbiol. Lett. 128, 229-234.

Cao, Y., Mu, H., Liu, W., Zhang, R., Guo, J., Xian, M., et al. (2019). Electricigens in the anode of microbial fuel cells: pure cultures versus mixed communities. Microb. Cell Fact. 18:39. doi: 10.1186/s12934-019-1087-z

Carniello, V., Peterson, B. W., Van Der Mei, H. C., and Busscher, H. J. (2018). Physico-chemistry from initial bacterial adhesion to surface-programmed biofilm growth. Adv. Colloid Interface Sci. 261, 1-14. doi: 10.1016/j.cis.2018.10. 005

Carter, M. Q., Louie, J. W., Feng, D., Zhong, W., and Brandl, M. T. (2016). Curli fimbriae are conditionally required in Escherichia coli O157:H7 for initial attachment and biofilm formation. Food Microbiol. 57, 81-89. doi: 10.1016/j.fm. 2016.01.006

Caruso, C., Rizzo, C., Mangano, S., Poli, A., Di Donato, P., Finore, I., et al. (2018). Production and biotechnological potential of extracellular polymeric substances from sponge-associated antarctic bacteria. Appl. Environ. Microbiol. 84:e01624-17. doi: 10.1128/AEM.01624-17

Cegelski, L., Pinkner, J. S., Hammer, N. D., Cusumano, C. K., Hung, C. S., Chorell, E., et al. (2009). Small-molecule inhibitors target Escherichia coli amyloid biogenesis and biofilm formation. Nat. Chem. Biol. 5, 913-919. doi: 10.1038/ nchembio. 242

Chan, S., Pullerits, K., Keucken, A., Persson, K. M., Paul, C. J., and Radstrom, P. (2019). Bacterial release from pipe biofilm in a full-scale drinking water distribution system. NPJ Biofilms Microbiomes 5:9. doi: 10.1038/s41522-0190082-9

Chavant, P., Martinie, B., Meylheuc, T., Bellon-Fontaine, M. N., and Hebraud, M. (2002). Listeria monocytogenes LO28: surface physicochemical properties and ability to form biofilms at different temperatures and growth phases. Appl. Environ. Microbiol. 68, 728-737.

Chen, F., Gao, Y., Chen, X., Yu, Z., and Li, X. (2013). Quorum quenching enzymes and their application in degrading signal molecules to block quorum sensing-dependent infection. Int. J. Mol. Sci. 14, 17477-17500. doi: 10.3390/ ijms140917477

Chen, S., Jing, X., Tang, J., Fang, Y., and Zhou, S. (2017). Quorum sensing signals enhance the electrochemical activity and energy recovery of mixed-culture electroactive biofilms. Biosens. Bioelectron. 97, 369-376. doi: 10.1016/j.bios. 2017.06.024

Chin-A-Woeng, T. F. C., Bloemberg, G. V., and Lugtenberg, B. J. J. (2003). Phenazines and their role in biocontrol by Pseudomonas bacteria. New Phytologist 157, 503-523.

Chmielewski, R. A. N., and Frank, J. F. (2003). Biofilm formation and control in food processing facilities. Compr. Rev. Food Sci. Food Safety 2, 22-32.

Chorell, E., Pinkner, J. S., Bengtsson, C., Edvinsson, S., Cusumano, C. K., Rosenbaum, E., et al. (2012). Design and synthesis of fluorescent pilicides and curlicides: bioactive tools to study bacterial virulence mechanisms. Chemistry 18, 4522-4532. doi: 10.1002/chem.201103936

Chung, P. Y., and Toh, Y. S. (2014). Anti-biofilm agents: recent breakthrough against multi-drug resistant Staphylococcus aureus. Pathog. Dis. 70, 231-239. doi: 10.1111/2049-632X.12141

Ciofu, O., and Tolker-Nielsen, T. (2019). Tolerance and resistance of Pseudomonas aeruginosa biofilms to antimicrobial agents-How $P$. aeruginosa can escape antibiotics. Front. Microbiol. 10:913. doi: 10.3389/fmicb.2019.00913

Cornejo, J. A., Lopez, C., Babanova, S., Santoro, C., Artyushkova, K., Ista, L., et al. (2015). Surface modi? cation for enhanced bio? $1 \mathrm{~m}$ formation and electron transport in shewanella anodes. J. Electrochem. Soc. 162, 597-603.

Costa, O. Y. A., Raaijmakers, J. M., and Kuramae, E. E. (2018). Microbial extracellular polymeric substances: ecological function and impact on soil aggregation. Front. Microbiol. 9:1636. doi: 10.3389/fmicb.2018.01636

Costa-Orlandi, C. B., Sardi, J. C. O., Pitangui, N. S., De Oliveira, H. C., Scorzoni, L., Galeane, M. C., et al. (2017). Fungal biofilms and polymicrobial diseases. J. Fungi (Basel) 3:22.

Coughlan, L. M., Cotter, P. D., Hill, C., and Alvarez-Ordonez, A. (2016). New weapons to fight old enemies: novel strategies for the (Bio)control of bacterial biofilms in the food industry. Front. Microbiol. 7:1641. doi: 10.3389/fmicb.2016. 01641

Dang, H., and Lovell, C. R. (2016). Microbial surface colonization and biofilm development in marine environments. Microbiol. Mol. Biol. Rev. 80, 91-138. doi: 10.1128/MMBR.00037-15

Danhorn, T., and Fuqua, C. (2007). Biofilm formation by plant-associated bacteria. Annu. Rev. Microbiol. 61, 401-422.

Das, K., Rajawat, M. V. S., Saxena, A. K., and Prasanna, R. (2017). Development of Mesorhizobium ciceri-based biofilms and analyses of their antifungal and plant growth promoting activity in chickpea challenged by Fusarium Wilt. Indian J. Microbiol. 57, 48-59. doi: 10.1007/s12088-016-0610-8

Dasgupta, D., Ghosh, R., and Sengupta, T. K. (2013). Biofilm-mediated enhanced crude oil degradation by newly isolated pseudomonas species. ISRN Biotechnol. 2013:250749. doi: 10.5402/2013/250749

Daud, M. K., Nafees, M., Ali, S., Rizwan, M., Bajwa, R. A., Shakoor, M. B., et al. (2017). Drinking water quality status and contamination in Pakistan. Biomed. Res. Int. 2017:7908183. doi: 10.1155/2017/7908183

de Carvalho, C. C. C. R. (2018). Marine biofilms: a successful microbial strategy with economic implications. Front. Mar. Sci. 5:126. doi: 10.3389/fmars.2018. 00126

de Vos, W. M. (2015). Microbial biofilms and the human intestinal microbiome. NPJ Biofilms Microbiomes 1:15005. doi: 10.1038/npjbiofilms.2015.5

Demirel, Y. K., Uzun, D., Zhang, Y., Fang, H. C., Day, A. H., and Turan, O. (2017). Effect of barnacle fouling on ship resistance and powering. Biofouling 33, 819-834. doi: 10.1080/08927014.2017.1373279

Dhir, S. (2013). Biofilm and dental implant: the microbial link. J. Indian Soc. Periodontol. 17, 5-11. doi: 10.4103/0972-124X.107466

Di Martino, P., Cafferini, N., Joly, B., and Darfeuille-Michaud, A. (2003). Klebsiella pneumoniae type 3 pili facilitate adherence and biofilm formation on abiotic surfaces. Res. Microbiol. 154, 9-16.

Diaz-Salazar, C., Calero, P., Espinosa-Portero, R., Jimenez-Fernandez, A., Wirebrand, L., Velasco-Dominguez, M. G., et al. (2017). The stringent response promotes biofilm dispersal in Pseudomonas putida. Sci. Rep. 7:18055. doi: 10. 1038/s41598-017-18518-0

Dickson, J. S., and Koohmaraie, M. (1989). Cell surface charge characteristics and their relationship to bacterial attachment to meat surfaces. Appl. Environ. Microbiol. 55, 832-836.

Dobretsov, S., Abed, R. M., and Teplitski, M. (2013). Mini-review: inhibition of biofouling by marine microorganisms. Biofouling 29, 423-441. doi: 10.1080/ 08927014.2013 .776042 
Dobretsov, S., Dahms, H. U., and Qian, P. Y. (2006). Inhibition of biofouling by marine microorganisms and their metabolites. Biofouling 22, 43-54.

Dogsa, I., Kriechbaum, M., Stopar, D., and Laggner, P. (2005). Structure of bacterial extracellular polymeric substances at different $\mathrm{pH}$ values as determined by SAXS. Biophys. J. 89, 2711-2720.

Dongari-Bagtzoglou, A. (2008). Pathogenesis of mucosal biofilm infections: challenges and progress. Expert Rev. Anti Infect. Ther. 6, 201-208. doi: 10.1586/ 14787210.6.2.201

Donlan, R. M. (2002). Biofilms: microbial life on surfaces. Emerg. Infect. Dis. 8, 881-890.

Donlan, R. M., and Costerton, J. W. (2002). Biofilms: survival mechanisms of clinically relevant microorganisms. Clin. Microbiol. Rev. 15, 167-193.

Douterelo, I., Husband, S., Loza, V., and Boxall, J. (2016). Dynamics of biofilm regrowth in drinking water distribution systems. Appl. Environ. Microbiol. 82, 4155-4168. doi: 10.1128/AEM.00109-16

Dror, N., Mandel, M., Hazan, Z., and Lavie, G. (2009). Advances in microbial biofilm prevention on indwelling medical devices with emphasis on usage of acoustic energy. Sensors (Basel) 9, 2538-2554. doi: 10.3390/s90402538

Dunne, W. M. Jr. (2002). Bacterial adhesion: seen any good biofilms lately? Clin. Microbiol. Rev. 15, 155-166.

Dziubakiewicz, E., Hrynkiewicz, K., Walczyk, M., and Buszewski, B. (2013). Study of charge distribution on the surface of biocolloids. Colloids Surf. B Biointerfaces 104, 122-127. doi: 10.1016/j.colsurfb.2012.11.018

Edwards, S. J., and Kjellerup, B. V. (2013). Applications of biofilms in bioremediation and biotransformation of persistent organic pollutants, pharmaceuticals/personal care products, and heavy metals. Appl. Microbiol. Biotechnol. 97, 9909-9921. doi: 10.1007/s00253-013-5216-z

El-Ganiny, A. M., Shaker, G. H., Aboelazm, A. A., and El-Dash, H. A. (2017). Prevention of bacterial biofilm formation on soft contact lenses using natural compounds. J. Ophthalmic. Inflamm. Infect. 7:11. doi: 10.1186/s12348-0170129-0

Elgharably, H., Hussain, S. T., Shrestha, N. K., Blackstone, E. H., and Pettersson, G. B. (2016). Current hypotheses in cardiac surgery: biofilm in infective endocarditis. Semin. Thorac. Cardiovasc. Surg. 28, 56-59. doi: 10.1053/ j.semtcvs.2015.12.005

Fahs, A., Quiles, F., Jamal, D., Humbert, F., and Francius, G. (2014). In situ analysis of bacterial extracellular polymeric substances from a Pseudomonas fluorescens biofilm by combined vibrational and single molecule force spectroscopies. J. Phys. Chem. B 118, 6702-6713. doi: 10.1021/jp5030872

Faille, C., Jullien, C., Fontaine, F., Bellon-Fontaine, M. N., Slomianny, C., and Benezech, T. (2002). Adhesion of Bacillus spores and Escherichia coli cells to inert surfaces: role of surface hydrophobicity. Can. J. Microbiol. 48, $728-738$.

Favero, B. M., Favero, A. C., Taffarel, S. R., and Souza, F. S. (2018). Evaluation of the efficiency of coagulation/flocculation and Fenton process in reduction of colour, turbidity and COD of a textile effluent. Environ. Technol. 41, 1580-1589.

Ference, C. M., Gochez, A. M., Behlau, F., Wang, N., Graham, J. H., and Jones, J. B. (2018). Recent advances in the understanding of Xanthomonas citri ssp. citri pathogenesis and citrus canker disease management. Mol. Plant Pathol. 19, 1302-1318. doi: $10.1111 / \mathrm{mpp} .12638$

Fira, D., Dimkic, I., Beric, T., Lozo, J., and Stankovic, S. (2018). Biological control of plant pathogens by Bacillus species. J. Biotechnol. 285, 44-55.

Fleming, D., and Rumbaugh, K. P. (2017). Approaches to dispersing medical biofilms. Microorganisms 5:15.

Flemming, H. C. (2016). EPS-then and now. Microorganisms 4:41.

Flemming, H. C., and Wingender, J. (2010). The biofilm matrix. Nat. Rev. Microbiol. 8, 623-633.

Flemming, H. C., Wingender, J., Szewzyk, U., Steinberg, P., Rice, S. A., and Kjelleberg, S. (2016). Biofilms: an emergent form of bacterial life. Nat. Rev. Microbiol. 14, 563-575.

Flemming, H. C., and Wuertz, S. (2019). Bacteria and archaea on Earth and their abundance in biofilms. Nat. Rev. Microbiol. 17, 247-260.

Flexer, V., Marque, M., Donose, B. C., Virdis, B., and Keller, J. (2013). Plasma treatment of electrodes significantly enhances the development of anodic electrochemically active biofilms. Electrochim. Acta 108, 566-574.

Flint, S. H., Brooks, J. D., and Bremer, P. J. (2000). Properties of the stainless steel substrate, influencing the adhesion of thermo-resistant streptococci. J. Food Eng. 43, 235-242.
Fong, J., Zhang, C., Yang, R., Boo, Z. Z., Tan, S. K., Nielsen, T. E., et al. (2018). Combination therapy strategy of quorum quenching enzyme and quorum sensing inhibitor in suppressing multiple quorum sensing pathways of $P$. aeruginosa. Sci. Rep. 8:1155.

Francis, M. R., Sarkar, R., Roy, S., Jaffar, S., Mohan, V. R., Kang, G., et al. (2016). Effectiveness of membrane filtration to improve drinking water: a quasiexperimental study from rural Southern India. Am. J. Trop. Med. Hyg. 95, 1192-1200.

Francolini, I., Vuotto, C., Piozzi, A., and Donelli, G. (2017). Antifouling and antimicrobial biomaterials: an overview. APMIS 125, 392-417.

Franks, A. E., Malvankar, N., and Nevin, K. P. (2010). Bacterial biofilms: the powerhouse of a microbial fuel cell. Biofuels 1, 589-604.

Franks, A. E., and Nevin, K. P. (2010). Microbial fuel cells. Curr. Rev. Energies 3, 899-919.

Frederick, M. R., Kuttler, C., Hense, B. A., and Eberl, H. J. (2011). A mathematical model of quorum sensing regulated EPS production in biofilm communities. Theor. Biol. Med. Model. 8:8.

Galie, S., Garcia-Gutierrez, C., Miguelez, E. M., Villar, C. J., and Lombo, F. (2018). Biofilms in the food industry: health aspects and control methods. Front. Microbiol. 9:898. doi: 10.3389/fmicb.2018.00898

Garnett, J. A., and Matthews, S. (2012). Interactions in bacterial biofilm development: a structural perspective. Curr. Protein Pept. Sci. 13, 739-755.

Gominet, M., Compain, F., Beloin, C., and Lebeaux, D. (2017). Central venous catheters and biofilms: where do we stand in 2017? APMIS 125, 365-375.

Gude, V. G. (2016a). " 8 - microbial fuel cells for wastewater treatment and energy generation," in Microbial Electrochemical and Fuel Cells, eds K. Scott and E. H. Yu (Boston, MA: Woodhead Publishing).

Gude, V. G. (2016b). Wastewater treatment in microbial fuel cells - an overview. J. Clean. Prod. 122, 287-307.

Guo, J., Yuan, S., Jiang, W., Lv, L., Liang, B., and Pehkonen, S. O. (2018). Polymers for combating biocorrosion. Front. Mater. 5:10. doi: 10.3389/fmats.2018.00010

Guttenplan, S. B., and Kearns, D. B. (2013). Regulation of flagellar motility during biofilm formation. FEMS Microbiol. Rev. 37, 849-871.

Haggag, W. M., and Timmusk, S. (2008). Colonization of peanut roots by biofilmforming Paenibacillus polymyxa initiates biocontrol against crown rot disease. J. Appl. Microbiol. 104, 961-969.

Haiko, J., and Westerlund-Wikstrom, B. (2013). The role of the bacterial flagellum in adhesion and virulence. Biology (Basel) 2, 1242-1267.

Hall-Stoodley, L., Costerton, J. W., and Stoodley, P. (2004). Bacterial biofilms: from the natural environment to infectious diseases. Nat. Rev. Microbiol. 2, 95-108.

Hall-Stoodley, L., and Stoodley, P. (2002). Developmental regulation of microbial biofilms. Curr. Opin. Biotechnol. 13, 228-233.

Han, N., Mizan, M. F. R., Jahid, I. K., and Ha, S.-D. (2016). Biofilm formation by Vibrio parahaemolyticus on food and food contact surfaces increases with rise in temperature. Food Control 70, 161-166.

Han, Q., Song, X., Zhang, Z., Fu, J., Wang, X., Malakar, P. K., et al. (2017). Removal of foodborne pathogen biofilms by acidic electrolyzed water. Front. Microbiol. 8:988. doi: 10.3389/fmicb.2017.00988

Hasan, J., Crawford, R. J., and Ivanova, E. P. (2013). Antibacterial surfaces: the quest for a new generation of biomaterials. Trends Biotechnol. 31, 295-304.

He, Y. R., Xiao, X., Li, W. W., Sheng, G. P., Yan, F. F., Yu, H. Q., et al. (2012). Enhanced electricity production from microbial fuel cells with plasma-modified carbon paper anode. Phys. Chem. Chem. Phys. 14, 9966-9971.

Heras, B., Totsika, M., Peters, K. M., Paxman, J. J., Gee, C. L., Jarrott, R. J., et al. (2014). The antigen 43 structure reveals a molecular Velcro-like mechanism of autotransporter-mediated bacterial clumping. Proc. Natl. Acad. Sci. U.S.A. 111, 457-462.

Hermansson, M. (1999). The DLVO theory in microbial adhesion. Colloids Surf. B Biointerfaces 14, 105-119.

Hibiya, K., Tsuneda, S., and Hirata, A. (2000). Formation and characteristics of nitrifying biofilm on a membrane modified with positively-charged polymer chains. Colloids Surf. B Biointerfaces 18, 105-112.

Hintsche, M., Waljor, V., Grossmann, R., Kuhn, M. J., Thormann, K. M., Peruani, F., et al. (2017). A polar bundle of flagella can drive bacterial swimming by pushing, pulling, or coiling around the cell body. Sci. Rep. 7:16771.

Hirakawa, H., and Tomita, H. (2013). Interference of bacterial cell-to-cell communication: a new concept of antimicrobial chemotherapy breaks antibiotic resistance. Front. Microbiol. 4:114. doi: 10.3389/fmicb.2013.00114 
Hlihor, R. M., Gavrilescu, M., Tavares, T., Favier, L., and Olivieri, G. (2017). Bioremediation: an overview on current practices, advances, and new perspectives in environmental pollution treatment. Biomed. Res. Int. 2017:6327610.

Hoffman, M. D., Zucker, L. I., Brown, P. J., Kysela, D. T., Brun, Y. V., and Jacobson, S. C. (2015). Timescales and frequencies of reversible and irreversible adhesion events of single bacterial cells. Anal. Chem. 87, 12032-12039.

Hopkins, G. A., and Forrest, B. M. (2010). A preliminary assessment of biofouling and non-indigenous marine species associated with commercial slow-moving vessels arriving in New Zealand. Biofouling 26, 613-621.

Huang, H., Peng, C., Peng, P., Lin, Y., Zhang, X., and Ren, H. (2019). Towards the biofilm characterization and regulation in biological wastewater treatment. Appl. Microbiol. Biotechnol. 103, 1115-1129.

Hughes, K. A., Sutherland, I. W., and Jones, M. V. (1998). Biofilm susceptibility to bacteriophage attack: the role of phage-borne polysaccharide depolymerase. Microbiology 144(Pt 11), 3039-3047.

Husmark, U., and Rönner, U. (1992). The influence of hydrophobic, electrostatic and morphologic properties on the adhesion of Bacillus spores. Biofouling 5 , 335-344.

Irankhah, S., Abdi Ali, A., Mallavarapu, M., Soudi, M. R., Subashchandrabose, S., Gharavi, S., et al. (2019). Ecological role of Acinetobacter calcoaceticus GSN3 in natural biofilm formation and its advantages in bioremediation. Biofouling 35, 377-391.

Jakobsen, T. H., Van Gennip, M., Phipps, R. K., Shanmugham, M. S., Christensen, L. D., Alhede, M., et al. (2012). Ajoene, a sulfur-rich molecule from garlic, inhibits genes controlled by quorum sensing. Antimicrob. Agents Chemother. 56, 2314-2325.

Jamal, M., Ahmad, W., Andleeb, S., Jalil, F., Imran, M., Nawaz, M. A., et al. (2018). Bacterial biofilm and associated infections. J. Chin. Med. Assoc. 81, 7-11.

Jayaraman, A., Cheng, E. T., Earthman, J. C., and Wood, T. K. (1997). Importance of biofilm formation for corrosion inhibition of SAE 1018 steel by axenic aerobic biofilms. J. Ind. Microbiol. Biotechnol. 18, 396-401.

Jayathilake, P. G., Jana, S., Rushton, S., Swailes, D., Bridgens, B., Curtis, T., et al. (2017). Extracellular polymeric substance production and aggregated bacteria colonization influence the competition of microbes in biofilms. Front. Microbiol. 8:1865. doi: 10.3389/fmicb.2017.01865

Jennings, J. A., Courtney, H. S., and Haggard, W. O. (2012). Cis-2-decenoic acid inhibits S. aureus growth and biofilm in vitro: a pilot study. Clin. Orthop. Relat. Res. 470, 2663-2670. doi: 10.1007/s11999-012-2388-2

Jia, R., Yang, D., Xu, D., and Gu, T. (2017). Mitigation of a nitrate reducing Pseudomonas aeruginosa biofilm and anaerobic biocorrosion using ciprofloxacin enhanced by D-tyrosine. Sci. Rep. 7:6946. doi: 10.1038/s41598017-07312-7

Jucker, B. A., Zehnder, A. J. B., and Harms, H. (1998). Quantification of polymer interactions in bacterial adhesion. Environ. Sci. Technol. 32, 2909-2915.

Kang, C. S., Eaktasang, N., Kwon, D. Y., and Kim, H. S. (2014). Enhanced current production by Desulfovibrio desulfuricans biofilm in a mediator-less microbial fuel cell. Bioresour. Technol. 165, 27-30. doi: 10.1016/j.biortech.2014.03.148

Kaplan, J. B. (2010). Biofilm dispersal: mechanisms, clinical implications, and potential therapeutic uses. J. Dent. Res. 89, 205-218. doi: 10.1177/ 0022034509359403

Kaplan, J. B. (2014). Biofilm matrix-degrading enzymes. Methods Mol. Biol. 1147, 203-213. doi: 10.1007/978-1-4939-0467-9_14

Kapley, A., and Purohit, H. J. (2009). Genomic tools in bioremediation. Indian J. Microbiol. 49, 108-113. doi: 10.1007/s12088-009-0012-2

Karatan, E., and Watnick, P. (2009). Signals, regulatory networks, and materials that build and break bacterial biofilms. Microbiol. Mol. Biol. Rev. 73, 310-347. doi: 10.1128/MMBR.00041-08

Karigar, C. S., and Rao, S. S. (2011). Role of microbial enzymes in the bioremediation of pollutants: a review. Enzyme Res. 2011:805187. doi: 10.4061/ 2011/805187

Karimi, A., Karig, D., Kumar, A., and Ardekani, A. M. (2015). Interplay of physical mechanisms and biofilm processes: review of microfluidic methods. Lab Chip 15, 23-42. doi: 10.1039/c4lc01095g

Katsikogianni, M., and Missirlis, Y. F. (2004). Concise review of mechanisms of bacterial adhesion to biomaterials and of techniques used in estimating bacteria-material interactions. Eur. Cell Mater. 8, 37-57.
Kearns, D. B. (2010). A field guide to bacterial swarming motility. Nat. Rev. Microbiol. 8, 634-644. doi: 10.1038/nrmicro2405

Khan, N., Martinez-Hidalgo, P., Ice, T. A., Maymon, M., Humm, E. A., Nejat, N., et al. (2018). Antifungal activity of Bacillus species against fusarium and analysis of the potential mechanisms used in biocontrol. Front. Microbiol. 9:2363. doi: 10.3389/fmicb.2018.02363

Khatoon, Z., Mctiernan, C. D., Suuronen, E. J., Mah, T. F., and Alarcon, E. I. (2018). Bacterial biofilm formation on implantable devices and approaches to its treatment and prevention. Heliyon 4:e01067. doi: 10.1016/j.heliyon.2018. e01067

Kip, N., and van Veen, J. A. (2015). The dual role of microbes in corrosion. ISME J. 9, 542-551. doi: 10.1038/ismej.2014.169

Kobya, M., Demirbas, E., and Akyol, A. (2009). Electrochemical treatment and operating cost analysis of textile wastewater using sacrificial iron electrodes. Water Sci. Technol. 60, 2261-2270. doi: 10.2166/wst.2009.672

Koczan, J. M., Lenneman, B. R., Mcgrath, M. J., and Sundin, G. W. (2011). Cell surface attachment structures contribute to biofilm formation and xylem colonization by Erwinia amylovora. Appl. Environ. Microbiol. 77, 7031-7039. doi: 10.1128/AEM.05138-11

Konto-Ghiorghi, Y., Mairey, E., Mallet, A., Dumenil, G., Caliot, E., Trieu-Cuot, P., et al. (2009). Dual role for pilus in adherence to epithelial cells and biofilm formation in Streptococcus agalactiae. PLoS Pathog. 5:e1000422. doi: 10.1371/ journal.ppat.1000422

Korber, D. R., Mangalappalli-Illathu, A. K., and Vidoviæ, S. (2009). “6 - biofilm formation by food spoilage microorganisms in food processing environments," in Biofilms in the Food and Beverage Industries, eds P. M. Fratamico, B. A. Annous, and N. W. Gunther (Sawston: Woodhead Publishing).

Kostakioti, M., Hadjifrangiskou, M., and Hultgren, S. J. (2013). Bacterial biofilms: development, dispersal, and therapeutic strategies in the dawn of the postantibiotic era. Cold Spring Harb. Perspect. Med. 3:a010306. doi: 10.1101/ cshperspect.a010306

Kuang, X., Chen, V., and Xu, X. (2018). Novel approaches to the control of oral microbial biofilms. Biomed. Res. Int. 2018:6498932. doi: 10.1155/2018/6498932

Kumar, C. G., and Anand, S. K. (1998). Significance of microbial biofilms in food industry: a review. Int. J. Food Microbiol. 42, 9-27.

Kyrkou, I., Pusa, T., Ellegaard-Jensen, L., Sagot, M. F., and Hansen, L. H. (2018). Pierce's disease of grapevines: a review of control strategies and an outline of an epidemiological model. Front. Microbiol. 9:2141. doi: 10.3389/fmicb.2018. 02141

Lackner, S., Holmberg, M., Terada, A., Kingshott, P., and Smets, B. F. (2009). Enhancing the formation and shear resistance of nitrifying biofilms on membranes by surface modification. Water Res. 43, 3469-3478. doi: 10.1016/ j.watres.2009.05.011

LeChevallier, M. W., Cawthon, C. D., and Lee, R. G. (1988). Inactivation of biofilm bacteria. Appl. Environ. Microbiol. 54, 2492-2499.

Lee, K., and Yoon, S. S. (2017). Pseudomonas aeruginosa biofilm, a programmed bacterial life for fitness. J. Microbiol. Biotechnol. 27, 1053-1064. doi: 10.4014/ jmb.1611.11056

Lemon, K. P., Higgins, D. E., and Kolter, R. (2007). Flagellar motility is critical for Listeria monocytogenes biofilm formation. J. Bacteriol. 189, 4418-4424.

Li, G., and Tang, J. X. (2009). Accumulation of microswimmers near a surface mediated by collision and rotational Brownian motion. Phys. Rev. Lett. 103:078101.

Li, Y. H., and Tian, X. (2012). Quorum sensing and bacterial social interactions in biofilms. Sensors (Basel) 12, 2519-2538.

Li, Z., Hu, W., Zhao, Y., Ren, L., and Yuan, X. (2018). Integrated antibacterial and antifouling surfaces via cross-linking chitosan-g-eugenol/zwitterionic copolymer on electrospun membranes. Colloids Surf. B Biointerfaces 169, 151159. doi: $10.1016 /$ j.colsurfb.2018.04.056

Limoli, D. H., Jones, C. J., and Wozniak, D. J. (2015). Bacterial extracellular polysaccharides in biofilm formation and function. Microbiol. Spectr. 3:10.1128/microbiolsec.MB-0011-2014.

Liu, H., Ramnarayanan, R., and Logan, B. E. (2004). Production of electricity during wastewater treatment using a single chamber microbial fuel cell. Environ. Sci. Technol. 38, 2281-2285.

Liu, S., Gunawan, C., Barraud, N., Rice, S. A., Harry, E. J., and Amal, R. (2016). Understanding, monitoring, and controlling biofilm growth in drinking water 
distribution systems. Environ. Sci. Technol. 50, 8954-8976. doi: 10.1021/acs.est. $6 \mathrm{~b} 00835$

Lopez, D., Vlamakis, H., and Kolter, R. (2010). Biofilms. Cold Spring Harb. Perspect. Biol. 2:a000398. doi: 10.1101/cshperspect.a000398

Lorite, G. S., Rodrigues, C. M., De Souza, A. A., Kranz, C., Mizaikoff, B., and Cotta, M. A. (2011). The role of conditioning film formation and surface chemical changes on Xylella fastidiosa adhesion and biofilm evolution. J. Colloid Interface Sci. 359, 289-295. doi: 10.1016/j.jcis.2011.03.066

Loveday, H. P., Wilson, J. A., Kerr, K., Pitchers, R., Walker, J. T., and Browne, J. (2014). Association between healthcare water systems and Pseudomonas aeruginosa infections: a rapid systematic review. J. Hosp. Infect. 86, 7-15. doi: 10.1016/j.jhin.2013.09.010

Lu, T. K., and Collins, J. J. (2007). Dispersing biofilms with engineered enzymatic bacteriophage. Proc. Natl. Acad. Sci. U.S.A. 104, 11197-11202.

Mahapatra, A., Padhi, N., Mahapatra, D., Bhatt, M., Sahoo, D., Jena, S., et al. (2015). Study of biofilm in bacteria from water pipelines. J. Clin. Diagn. Res. 9, DC09-DC11. doi: 10.7860/JCDR/2015/12415.5715

Maldarelli, G. A., Piepenbrink, K. H., Scott, A. J., Freiberg, J. A., Song, Y., Achermann, Y., et al. (2016). Type IV pili promote early biofilm formation by Clostridium difficile. Pathog. Dis. 74:ftw061. doi: 10.1093/femspd/ftw061

Mangwani, N., Kumari, S., and Das, S. (2015). Involvement of quorum sensing genes in biofilm development and degradation of polycyclic aromatic hydrocarbons by a marine bacterium Pseudomonas aeruginosa N6P6. Appl. Microbiol. Biotechnol. 99, 10283-10297. doi: 10.1007/s00253-015-6868-7

Mangwani, N., Kumari, S., and Das, S. (2016). Bacterial biofilms and quorum sensing: fidelity in bioremediation technology. Biotechnol. Genet. Eng. Rev. 32, 43-73. doi: 10.1080/02648725.2016.1196554

Martinez, P., Vera, M., and Bobadilla-Fazzini, R. A. (2015). Omics on bioleaching: current and future impacts. Appl. Microbiol. Biotechnol. 99, 8337-8350. doi: 10.1007/s00253-015-6903-8

Masters, E. A., Trombetta, R. P., De Mesy Bentley, K. L., Boyce, B. F., Gill, A. L., Gill, S. R., et al. (2019). Evolving concepts in bone infection: redefining "biofilm", "acute vs. chronic osteomyelitis", "the immune proteome" and "local antibiotic therapy”. Bone Res. 7:20. doi: 10.1038/s41413-019-0061-z

Meena, K. R., and Kanwar, S. S. (2015). Lipopeptides as the antifungal and antibacterial agents: applications in food safety and therapeutics. Biomed. Res. Int. 2015:473050. doi: 10.1155/2015/473050

Meesilp, N., and Mesil, N. (2019). Effect of microbial sanitizers for reducing biofilm formation of Staphylococcus aureus and Pseudomonas aeruginosa on stainless steel by cultivation with UHT milk. Food Sci. Biotechnol. 28, 289-296. doi: 10.1007/s10068-018-0448-4

Mei, X., Xing, D., Yang, Y., Liu, Q., Zhou, H., Guo, C., et al. (2017). Adaptation of microbial community of the anode biofilm in microbial fuel cells to temperature. Bioelectrochemistry 117, 29-33. doi: 10.1016/j.bioelechem.2017. 04.005

Miller, M. B., and Bassler, B. L. (2001). Quorum sensing in bacteria. Annu. Rev. Microbiol. 55, 165-199.

Min, B., Kim, J., Oh, S., Regan, J. M., and Logan, B. E. (2005). Electricity generation from swine wastewater using microbial fuel cells. Water Res. 39, 4961-4968.

Minchin, D., and Gollasch, S. (2003). Fouling and ships' hulls: how changing circumstances and spawning events may result in the spread of exotic species. Biofouling 19(Suppl), 111-122.

Monier, J. M., and Lindow, S. E. (2004). Frequency, size, and localization of bacterial aggregates on bean leaf surfaces. Appl. Environ. Microbiol. 70, 346355.

Møretrø, T., and Langsrud, S. (2017). Residential bacteria on surfaces in the food industry and their implications for food safety and quality. Compr. Rev. Food Sci. Food Safety 16, 1022-1041.

Mori, Y., Inoue, K., Ikeda, K., Nakayashiki, H., Higashimoto, C., Ohnishi, K., et al. (2016). The vascular plant-pathogenic bacterium Ralstonia solanacearum produces biofilms required for its virulence on the surfaces of tomato cells adjacent to intercellular spaces. Mol. Plant Pathol. 17, 890-902. doi: 10.1111/ mpp. 12335

Morikawa, M. (2006). Beneficial biofilm formation by industrial bacteria Bacillus subtilis and related species. J. Biosci. Bioeng. 101, 1-8.

Morra, M., and Cassinelli, C. (1997). Bacterial adhesion to polymer surfaces: a critical review of surface thermodynamic approaches. J. Biomater. Sci. Polym. Ed 9, 55-74.
Murphy, C. N., Mortensen, M. S., Krogfelt, K. A., and Clegg, S. (2013). Role of Klebsiella pneumoniae type 1 and type 3 fimbriae in colonizing silicone tubes implanted into the bladders of mice as a model of catheter-associated urinary tract infections. Infect. Immun. 81, 3009-3017. doi: 10.1128/IAI. 00348-13

Murugan, K., Selvanayaki, K., and Al-Sohaibani, S. (2016). Urinary catheter indwelling clinical pathogen biofilm formation, exopolysaccharide characterization and their growth influencing parameters. Saudi J. Biol. Sci. 23, 150-159. doi: 10.1016/j.sjbs.2015.04.016

Musthafa, K. S., Ravi, A. V., Annapoorani, A., Packiavathy, I. S., and Pandian, S. K. (2010). Evaluation of anti-quorum-sensing activity of edible plants and fruits through inhibition of the $\mathrm{N}$-acyl-homoserine lactone system in Chromobacterium violaceum and Pseudomonas aeruginosa. Chemotherapy 56, 333-339. doi: 10.1159/000320185

Myszka, K., and Czaczyk, K. (2009). Characterization of adhesive exopolysaccharide (EPS) produced by Pseudomonas aeruginosa under starvation conditions. Curr. Microbiol. 58, 541-546. doi: 10.1007/s00284-0099365-3

Naidoo, S., and Olaniran, A. O. (2013). Treated wastewater effluent as a source of microbial pollution of surface water resources. Int. J. Environ. Res. Public Health 11, 249-270. doi: 10.3390/ijerph110100249

O’Toole, G., Kaplan, H. B., and Kolter, R. (2000). Biofilm formation as microbial development. Annu. Rev. Microbiol. 54, 49-79.

Packiavathy, I. A., Priya, S., Pandian, S. K., and Ravi, A. V. (2014). Inhibition of biofilm development of uropathogens by curcumin - an anti-quorum sensing agent from Curcuma longa. Food Chem. 148, 453-460. doi: 10.1016/j.foodchem. 2012.08.002

Pajkos, A., Deva, A. K., Vickery, K., Cope, C., Chang, L., and Cossart, Y. E. (2003). Detection of subclinical infection in significant breast implant capsules. Plast. Reconstr. Surg. 111, 1605-1611.

Pakharukova, N., Tuittila, M., Paavilainen, S., Malmi, H., Parilova, O., Teneberg, S., et al. (2018). Structural basis for Acinetobacter baumannii biofilm formation. Proc. Natl. Acad. Sci. U.S.A. 115, 5558-5563.

Pal, Z., Urban, E., Dosa, E., Pal, A., and Nagy, E. (2005). Biofilm formation on intrauterine devices in relation to duration of use. J. Med. Microbiol. 54, 1199-1203.

Palmer, J., Flint, S., and Brooks, J. (2007). Bacterial cell attachment, the beginning of a biofilm. J. Ind. Microbiol. Biotechnol. 34, 577-588.

Pandin, C., Le Coq, D., Canette, A., Aymerich, S., and Briandet, R. (2017). Should the biofilm mode of life be taken into consideration for microbial biocontrol agents? Microb. Biotechnol. 10, 719-734.

Papenfort, K., and Bassler, B. L. (2016). Quorum sensing signal-response systems in Gram-negative bacteria. Nat. Rev. Microbiol. 14, 576-588.

Parrino, B., Schillaci, D., Carnevale, I., Giovannetti, E., Diana, P., Cirrincione, G., et al. (2019). Synthetic small molecules as anti-biofilm agents in the struggle against antibiotic resistance. Eur. J. Med. Chem. 161, 154-178.

Pedersen, K. (1990). Biofilm development on stainless steel and pvc surfaces in drinking water. Water Res. 24, 239-243.

Percival, S. L., Suleman, L., Vuotto, C., and Donelli, G. (2015). Healthcareassociated infections, medical devices and biofilms: risk, tolerance and control. J. Med. Microbiol. 64, 323-334.

Perni, S., Preedy, E. C., and Prokopovich, P. (2014). Success and failure of colloidal approaches in adhesion of microorganisms to surfaces. Adv. Colloid Interface Sci. 206, 265-274.

Petrova, O. E., Schurr, J. R., Schurr, M. J., and Sauer, K. (2012). Microcolony formation by the opportunistic pathogen Pseudomonas aeruginosa requires pyruvate and pyruvate fermentation. Mol. Microbiol. 86, 819-835.

Pihl, M., Davies, J. R., Johansson, A. C., and Svensater, G. (2013). Bacteria on catheters in patients undergoing peritoneal dialysis. Perit. Dial. Int. 33, 51-59.

Ponnusamy, K., Paul, D., Sam Kim, Y., and Kweon, J. H. (2010). 2(5H)-Furanone: a prospective strategy for biofouling-control in membrane biofilm bacteria by quorum sensing inhibition. Braz. J. Microbiol. 41, 227-234.

Porter, S. L., Wadhams, G. H., and Armitage, J. P. (2011). Signal processing in complex chemotaxis pathways. Nat. Rev. Microbiol. 9, 153-165.

Prest, E. I., Hammes, F., Van Loosdrecht, M. C., and Vrouwenvelder, J. S. (2016). Biological stability of drinking water: controlling factors, methods, and challenges. Front. Microbiol. 7:45. doi: 10.3389/fmicb.2016. 00045 
Rabin, N., Zheng, Y., Opoku-Temeng, C., Du, Y., Bonsu, E., and Sintim, H. O. (2015). Biofilm formation mechanisms and targets for developing antibiofilm agents. Future Med. Chem. 7, 493-512.

Raghupathi, P. K., Liu, W., Sabbe, K., Houf, K., Burmolle, M., and Sorensen, S. J. (2017). Synergistic interactions within a multispecies biofilm enhance individual species protection against grazing by a pelagic protozoan. Front. Microbiol. 8:2649. doi: 10.3389/fmicb.2017.02649

Rahman, M., Kim, S., Kim, S. M., Seol, S. Y., and Kim, J. (2011). Characterization of induced Staphylococcus aureus bacteriophage Sap-26 and its anti-biofilm activity with rifampicin. Biofouling 27, 1087-1093.

Rajmohan, S., Dodd, C. E., and Waites, W. M. (2002). Enzymes from isolates of Pseudomonas fluorescens involved in food spoilage. J. Appl. Microbiol. 93, 205-213.

Remy, B., Mion, S., Plener, L., Elias, M., Chabriere, E., and Daude, D. (2018). Interference in bacterial quorum sensing: a biopharmaceutical perspective. Front. Pharmacol. 9:203. doi: 10.3389/fphar.2018.00203

Ren, L., Mccuskey, S. R., Moreland, A., Bazan, G. C., and Nguyen, T.-Q. (2019). Tuning Geobacter sulfurreducens biofilm with conjugated polyelectrolyte for increased performance in bioelectrochemical system. Biosens. Bioelectron. 144:111630.

Ren, Z., Steinberg, L. M., and Regan, J. M. (2008). Electricity production and microbial biofilm characterization in cellulose-fed microbial fuel cells. Water Sci. Technol. 58, 617-622.

Renner, L. D., and Weibel, D. B. (2011). Physicochemical regulation of biofilm formation. MRS Bull. 36, 347-355.

Rieger, U. M., Mesina, J., Kalbermatten, D. F., Haug, M., Frey, H. P., Pico, R., et al. (2013). Bacterial biofilms and capsular contracture in patients with breast implants. Br. J. Surg. 100, 768-774.

Rijnaarts, H. H. M., Norde, W., Lyklema, J., and Zehnder, A. J. B. (1999). DLVO and steric contributions to bacterial deposition in media of different ionic strengths. Colloids Surf. B Biointerfaces 14, 179-195.

Rivas, L., Fegan, N., and Dykes, G. A. (2007). Attachment of Shiga toxigenic Escherichia coli to stainless steel. Int. J. Food Microbiol. 115, 89-94.

Roder, H. L., Herschend, J., Russel, J., Andersen, M. F., Madsen, J. S., Sorensen, S. J., et al. (2018). Enhanced bacterial mutualism through an evolved biofilm phenotype. ISME J. 12, 2608-2618.

Rodriguez-Martinez, E. M., Perez, E. X., Schadt, C. W., Zhou, J., and MassolDeya, A. A. (2006). Microbial diversity and bioremediation of a hydrocarboncontaminated aquifer (Vega Baja, Puerto Rico). Int. J. Environ. Res. Public Health 3, 292-300.

Rogers, J., Dowsett, A. B., Dennis, P. J., Lee, J. V., and Keevil, C. W. (1994). Influence of plumbing materials on biofilm formation and growth of Legionella pneumophila in potable water systems. Appl. Environ. Microbiol. 60, 1842-1851.

Rohde, H., Frankenberger, S., Zahringer, U., and Mack, D. (2010). Structure, function and contribution of polysaccharide intercellular adhesin (PIA) to Staphylococcus epidermidis biofilm formation and pathogenesis of biomaterialassociated infections. Eur. J. Cell Biol. 89, 103-111.

Roosjen, A., De Vries, J., Van Der Mei, H. C., Norde, W., and Busscher, H. J. (2005). Stability and effectiveness against bacterial adhesion of poly(ethylene oxide) coatings in biological fluids. J. Biomed. Mater. Res. B Appl. Biomater. 73, 347-354.

Roosjen, A., Kaper, H. J., Van Der Mei, H. C., Norde, W., and Busscher, H. J. (2003). Inhibition of adhesion of yeasts and bacteria by poly(ethylene oxide)-brushes on glass in a parallel plate flow chamber. Microbiology 149, 3239-3246.

Rosche, B., Li, X. Z., Hauer, B., Schmid, A., and Buehler, K. (2009). Microbial biofilms: a concept for industrial catalysis? Trends Biotechnol. 27, 636-643.

Rudrappa, T., Biedrzycki, M. L., and Bais, H. P. (2008). Causes and consequences of plant-associated biofilms. FEMS Microbiol. Ecol. 64, 153-166.

Sadekuzzaman, M., Yang, S., Mizan, M. F. R., and Ha, S. D. (2015). Current and recent advanced strategies for combating biofilms. Compr. Rev. Food Sci. Food Safety 14, 491-509.

Sanchez, E., Rivas Morales, C., Castillo, S., Leos-Rivas, C., Garcia-Becerra, L., and Ortiz Martinez, D. M. (2016). Antibacterial and antibiofilm activity of methanolic plant extracts against nosocomial microorganisms. Evid. Based Complement. Alternat. Med. 2016:1572697.

Santos, A., Galdino, A. C. M., Mello, T. P., Ramos, L. S., Branquinha, M. H., Bolognese, A. M., et al. (2018). What are the advantages of living in a community? A microbial biofilm perspective! Mem. Inst. Oswaldo Cruz. 113:e180212.

Santos, A. P., Watanabe, E., and Andrade, D. (2011). Biofilm on artificial pacemaker: fiction or reality? Arq. Bras. Cardiol. 97, e113-e120.

Sao-Jose, C. (2018). Engineering of phage-derived lytic enzymes: improving their potential as antimicrobials. Antibiotics (Basel) 7:29.

Schirawski, J., and Perlin, M. H. (2018). Plant(-)microbe interaction 2017-the good, the bad and the diverse. Int. J. Mol. Sci. 19:1374.

Schultz, M. P., Bendick, J. A., Holm, E. R., and Hertel, W. M. (2011). Economic impact of biofouling on a naval surface ship. Biofouling 27, 87-98.

Sharahi, J. Y., Azimi, T., Shariati, A., Safari, H., Tehrani, M. K., and Hashemi, A. (2019). Advanced strategies for combating bacterial biofilms. J. Cell. Physiol. 234, 14689-14708.

Shen, D., Langenheder, S., and Jurgens, K. (2018). Dispersal modifies the diversity and composition of active bacterial communities in response to a salinity disturbance. Front. Microbiol. 9:2188. doi: 10.3389/fmicb.2018.02188

Shirey, T. B., Thacker, R. W., and Olson, J. B. (2012). Composition and stability of bacterial communities associated with granular activated carbon and anthracite filters in a pilot scale municipal drinking water treatment facility. J. Water Health 10, 244-255.

Shokouhfard, M., Kermanshahi, R. K., Shahandashti, R. V., Feizabadi, M. M., and Teimourian, S. (2015). The inhibitory effect of a Lactobacillus acidophilus derived biosurfactant on biofilm producer Serratia marcescens. Iran J. Basic Med. Sci. 18, 1001-1007.

Siezen, R. J., and Wilson, G. (2009). Bioleaching genomics. Microb. Biotechnol. 2, 297-303.

Silva, V. O., Soares, L. O., Silva Junior, A., Mantovani, H. C., Chang, Y. F., and Moreira, M. A. (2014). Biofilm formation on biotic and abiotic surfaces in the presence of antimicrobials by Escherichia coli Isolates from cases of bovine mastitis. Appl. Environ. Microbiol. 80, 6136-6145.

Simmons, M., Drescher, K., Nadell, C. D., and Bucci, V. (2018). Phage mobility is a core determinant of phage-bacteria coexistence in biofilms. ISME J. 12, 531-543.

Simpson, D. R. (2008). Biofilm processes in biologically active carbon water purification. Water Res. 42, 2839-2848.

Singh, H. M., Pathak, A. K., Chopra, K., Tyagi, V. V., Anand, S., and Kothari, R. (2019). Microbial fuel cells: a sustainable solution for bioelectricity generation and wastewater treatment. Biofuels 10, 11-31.

Singh, P. K., Bartalomej, S., Hartmann, R., Jeckel, H., Vidakovic, L., Nadell, C. D., et al. (2017). Vibrio cholerae combines individual and collective sensing to trigger biofilm dispersal. Curr. Biol. 27, 3359-3366.e7.

Singh, R., Paul, D., and Jain, R. K. (2006). Biofilms: implications in bioremediation. Trends Microbiol. 14, 389-397.

Somers, E. B., and Wong, A. C. (2004). Efficacy of two cleaning and sanitizing combinations on Listeria monocytogenes biofilms formed at low temperature on a variety of materials in the presence of ready-to-eat meat residue. J. Food Prot. 67, 2218-2229.

Somogyi-Ganss, E., Chambers, M. S., Lewin, J. S., Tarrand, J. J., and Hutcheson, K. A. (2017). Biofilm on the tracheoesophageal voice prosthesis: considerations for oral decontamination. Eur. Arch. Otorhinolaryngol. 274, 405-413.

Sousa, C., Rodrigues, D., Oliveira, R., Song, W., Mano, J. F., and Azeredo, J. (2011). Superhydrophobic poly(L-lactic acid) surface as potential bacterial colonization substrate. AMB Express 1:34.

Southey-Pillig, C. J., Davies, D. G., and Sauer, K. (2005). Characterization of temporal protein production in Pseudomonas aeruginosa biofilms. J. Bacteriol. $187,8114-8126$.

Sperandio, V., Torres, A. G., Giron, J. A., and Kaper, J. B. (2001). Quorum sensing is a global regulatory mechanism in enterohemorrhagic Escherichia coli O157:H7. J. Bacteriol. 183, 5187-5197.

Srey, S., Jahid, I. K., and Ha, S.-D. (2013). Biofilm formation in food industries: a food safety concern. Food Control 31, 572-585.

Steddom, K., Menge, J. A., Crowley, D., and Borneman, J. (2002). Effect of repetitive applications of the biocontrol bacterium Pseudomonas putida 06909-rif/nal on citrus soil microbial communities. Phytopathology 92, 857-862.

Stein, T. (2005). Bacillus subtilis antibiotics: structures, syntheses and specific functions. Mol. Microbiol. 56, 845-857.

Stoodley, P., Sauer, K., Davies, D. G., and Costerton, J. W. (2002). Biofilms as complex differentiated communities. Annu. Rev. Microbiol. 56, 187-209. 
Sun, J., Daniel, R., Wagner-Dobler, I., and Zeng, A. P. (2004). Is autoinducer-2 a universal signal for interspecies communication: a comparative genomic and phylogenetic analysis of the synthesis and signal transduction pathways. BMC Evol. Biol. 4:36. doi: 10.1186/1471-2148-4-36

Sweet, M. J., Croquer, A., and Bythell, J. C. (2011). Development of bacterial biofilms on artificial corals in comparison to surface-associated microbes of hard corals. PLoS One 6:e21195. doi: 10.1371/journal.pone.0021195

Teixeira, P., and Oliveira, R. (1999). Influence of surface characteristics on the adhesion of Alcaligenes denitrificans to polymeric substrates. J. Adhes. Sci. Technol. 13, 1287-1294.

Terada, A., Yamamoto, T., Hibiya, K., Tsuneda, S., and Hirata, A. (2004). Enhancement of biofilm formation onto surface-modified hollow-fiber membranes and its application to a membrane-aerated biofilm reactor. Water Sci. Technol. 49, 263-268.

Terashima, H., Kojima, S., and Homma, M. (2008). Flagellar motility in bacteria structure and function of flagellar motor. Int. Rev. Cell Mol. Biol. 270, 39-85. doi: 10.1016/S1937-6448(08)01402-0

Timmusk, S., Behers, L., Muthoni, J., Muraya, A., and Aronsson, A. C. (2017). Perspectives and challenges of microbial application for crop improvement. Front. Plant Sci. 8:49. doi: 10.3389/fpls.2017.00049

Tomaras, A. P., Dorsey, C. W., Edelmann, R. E., and Actis, L. A. (2003). Attachment to and biofilm formation on abiotic surfaces by Acinetobacter baumannii: involvement of a novel chaperone-usher pili assembly system. Microbiology 149, 3473-3484. doi: 10.1099/mic.0.26541-0

Toyofuku, M., Inaba, T., Kiyokawa, T., Obana, N., Yawata, Y., and Nomura, N. (2016). Environmental factors that shape biofilm formation. Biosci. Biotechnol. Biochem. 80, 7-12. doi: 10.1080/09168451.2015.1058701

Tremblay, Y. D., Levesque, C., Segers, R. P., and Jacques, M. (2013). Method to grow Actinobacillus pleuropneumoniae biofilm on a biotic surface. BMC Vet. Res. 9:213. doi: 10.1186/1746-6148-9-213

Truchado, P., Gimenez-Bastida, J. A., Larrosa, M., Castro-Ibanez, I., Espin, J. C., Tomas-Barberan, F. A., et al. (2012). Inhibition of quorum sensing (QS) in Yersinia enterocolitica by an orange extract rich in glycosylated flavanones. J. Agric. Food Chem. 60, 8885-8894.

Tuson, H. H., and Weibel, D. B. (2013). Bacteria-surface interactions. Soft Matter 9, 4368-4380.

Ukuku, D. O., and Fett, W. F. (2002). Relationship of cell surface charge and hydrophobicity to strength of attachment of bacteria to cantaloupe rind. J. Food Prot. 65, 1093-1099.

Upadhyayula, V. K., and Gadhamshetty, V. (2010). Appreciating the role of carbon nanotube composites in preventing biofouling and promoting biofilms on material surfaces in environmental engineering: a review. Biotechnol. Adv. 28, 802-816. doi: 10.1016/j.biotechadv.2010.06.006

Vacheethasanee, K., Temenoff, J. S., Higashi, J. M., Gary, A., Anderson, J. M., Bayston, R., et al. (1998). Bacterial surface properties of clinically isolated Staphylococcus epidermidis strains determine adhesion on polyethylene. J. Biomed. Mater. Res. 42, 425-432.

Vaishnavi, C., Samanta, J., and Kochhar, R. (2018). Characterization of biofilms in biliary stents and potential factors involved in occlusion. World J. Gastroenterol. 24, 112-123. doi: 10.3748/wjg.v24.i1.112

van Dillewijn, P., Nojiri, H., Van Der Meer, J. R., and Wood, T. K. (2009). Bioremediation, a broad perspective. Microb. Biotechnol. 2, 125-127.

Van Houdt, R., and Michiels, C. W. (2005). Role of bacterial cell surface structures in Escherichia coli biofilm formation. Res. Microbiol. 156, 626-633.

Van Houdt, R., and Michiels, C. W. (2010). Biofilm formation and the food industry, a focus on the bacterial outer surface. J. Appl. Microbiol. 109, $1117-$ 1131. doi: 10.1111/j.1365-2672.2010.04756.x

Vanhaecke, E., Remon, J. P., Moors, M., Raes, F., De Rudder, D., and Van Peteghem, A. (1990). Kinetics of Pseudomonas aeruginosa adhesion to 304 and 316-L stainless steel: role of cell surface hydrophobicity. Appl. Environ. Microbiol. 56, 788-795.

Vasilev, K., Cavallaro, A., and Zilm, P. (2018). Special Issue: antibacterial materials and coatings. Molecules 23:585.

Vatanyoopaisarn, S., Nazli, A., Dodd, C. E., Rees, C. E., and Waites, W. M. (2000). Effect of flagella on initial attachment of Listeria monocytogenes to stainless steel. Appl. Environ. Microbiol. 66, 860-863.

Veerachamy, S., Yarlagadda, T., Manivasagam, G., and Yarlagadda, P. K. (2014). Bacterial adherence and biofilm formation on medical implants: a review. Proc. Inst. Mech. Eng. H 228, 1083-1099. doi: 10.1177/0954411914556137
Vejan, P., Abdullah, R., Khadiran, T., Ismail, S., and Nasrulhaq Boyce, A. (2016). Role of plant growth promoting Rhizobacteria in agricultural sustainability-a review. Molecules 21:573. doi: 10.3390/molecules 21050573

Vladimirov, N., and Sourjik, V. (2009). Chemotaxis: how bacteria use memory. Biol. Chem. 390, 1097-1104. doi: 10.1515/BC.2009.130

Wei, Q., and Ma, L. Z. (2013). Biofilm matrix and its regulation in Pseudomonas aeruginosa. Int. J. Mol. Sci. 14, 20983-21005. doi: 10.3390/ijms141020983

Wirtanen, G., and Salo, S. (2016). "Chapter 5 - biofilm risks," in Handbook of Hygiene Control in the Food Industry (Second Edition), eds H. Lelieveld, J. Holah, and D. Gabriæ (San Diego, CA: Woodhead Publishing).

Wood, T. K. (2013). Precedence for the structural role of flagella in biofilms. mBio 4:e00225-13.

Wu, H., Moser, C., Wang, H. Z., Hoiby, N., and Song, Z. J. (2015). Strategies for combating bacterial biofilm infections. Int. J. Oral Sci. 7, 1-7. doi: 10.1038/ijos. 2014.65

Xu, Q., Barrios, C. A., Cutright, T., and Newby, B. M. (2005). Assessment of antifouling effectiveness of two natural product antifoulants by attachment study with freshwater bacteria. Environ. Sci. Pollut. Res. Int. 12, 278-284.

Yamashita, T., and Yamamoto-Ikemoto, R. (2014). Nitrogen and phosphorus removal from wastewater treatment plant effluent via bacterial sulfate reduction in an anoxic bioreactor packed with wood and iron. Int. J. Environ. Res. Public Health 11, 9835-9853. doi: 10.3390/ijerph110909835

Yao, J., and Allen, C. (2007). The plant pathogen Ralstonia solanacearum needs aerotaxis for normal biofilm formation and interactions with its tomato host. J. Bacteriol. 189, 6415-6424.

Yeung, P. S., and Boor, K. J. (2004). Epidemiology, pathogenesis, and prevention of foodborne Vibrio parahaemolyticus infections. Foodborne Pathog. Dis. 1, 74-88.

Yoshikawa, M., Zhang, M., and Toyota, K. (2017). Integrated anaerobic-aerobic biodegradation of multiple contaminants including chlorinated ethylenes, benzene, toluene, and dichloromethane. Water Air Soil Pollut. 228:25.

Yu, P., Wang, C., Zhou, J., Jiang, L., Xue, J., and Li, W. (2016). Influence of surface properties on adhesion forces and attachment of Streptococcus mutans to Zirconia In Vitro. Biomed. Res. Int. 2016:8901253.

Zhang, X., Brodus, D., Hollimon, V., and Hu, H. (2017). A brief review of recent developments in the designs that prevent bio-fouling on silicon and silicon-based materials. Chem. Cent. J. 11:18.

Zhang, X., Zhang, Q., Yan, T., Jiang, Z., Zhang, X., and Zuo, Y. Y. (2015). Quantitatively predicting bacterial adhesion using surface free energy determined with a spectrophotometric method. Environ. Sci. Technol. 49, 6164-6171.

Zhao, B., Van Der Mei, H. C., Subbiahdoss, G., De Vries, J., Rustema-Abbing, M., Kuijer, R., et al. (2014). Soft tissue integration versus early biofilm formation on different dental implant materials. Dent. Mater. 30, 716-727.

Zielinska, M., Rusanowska, P., Jarzabek, J., and Nielsen, J. L. (2016). Community dynamics of denitrifying bacteria in full-scale wastewater treatment plants. Environ. Technol. 37, 2358-2367.

Zimmerli, W., and Sendi, P. (2017). Orthopaedic biofilm infections. APMIS 125, 353-364. doi: 10.1111/apm.12687

Zottola, E. A., and Sasahara, K. C. (1994). Microbial biofilms in the food processing industry-should they be a concern? Int. J. Food Microbiol. 23, 125-148.

Zuo, R. (2007). Biofilms: strategies for metal corrosion inhibition employing microorganisms. Appl. Microbiol. Biotechnol. 76, 1245-1253.

Zuo, R., Ornek, D., Syrett, B. C., Green, R. M., Hsu, C. H., Mansfeld, F. B., et al. (2004). Inhibiting mild steel corrosion from sulfate-reducing bacteria using antimicrobial-producing biofilms in Three-Mile-Island process water. Appl. Microbiol. Biotechnol. 64, 275-283.

Conflict of Interest: The authors declare that the research was conducted in the absence of any commercial or financial relationships that could be construed as a potential conflict of interest.

Copyright (c) 2020 Muhammad, Idris, Fan, Guo, Yu, Jin, Qiu, Guan and Huang. This is an open-access article distributed under the terms of the Creative Commons Attribution License (CC BY). The use, distribution or reproduction in other forums is permitted, provided the original author(s) and the copyright owner(s) are credited and that the original publication in this journal is cited, in accordance with accepted academic practice. No use, distribution or reproduction is permitted which does not comply with these terms. 